
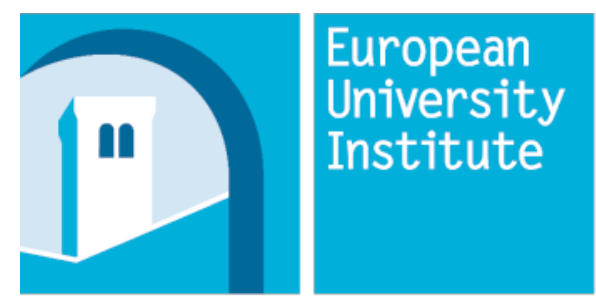

\title{
MAX WEBER
}

PROGRAMME FOR

POSTDOCTORAL

STUDIES

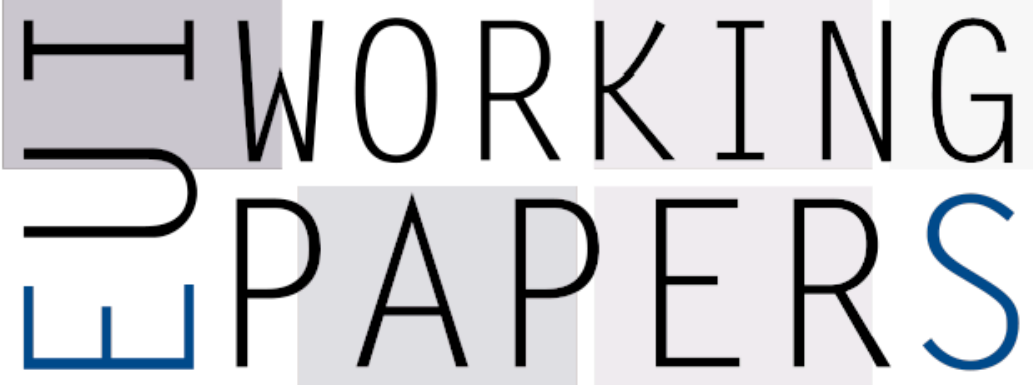

MWP 2016/12

Max Weber Programme

Regulating Corporate Regulators through Contract Law? The Case of Corporate Social Responsibility Codes of Conduct

Anna Beckers 

European University Institute Max Weber Programme

Regulating Corporate Regulators through Contract Law? The Case of Corporate Social Responsibility Codes of Conduct

Anna Beckers

EUI Working Paper MWP 2016/12 
This text may be downloaded for personal research purposes only. Any additional reproduction for other purposes, whether in hard copy or electronically, requires the consent of the author(s), editor(s). If cited or quoted, reference should be made to the full name of the author(s), editor(s), the title, the working paper or other series, the year, and the publisher.

ISSN $1830-7728$

(C) Anna Beckers, 2016

Printed in Italy

European University Institute

Badia Fiesolana

I - 50014 San Domenico di Fiesole (FI)

Italy

www.eui.eu

cadmus.eui.eu 


\begin{abstract}
Codes of conduct transcend the boundaries between the concepts of self-regulation, contract and regulation. This contribution focuses specifically on the phenomenon of corporate codes of conduct and argues that these codes can be described as a genuine form of regulation initiated by corporations, which as a consequence requires private law as the applicable legal framework to become more regulatory itself. In the context of this paper, corporate codes are defined as unilateral selfcommitments by companies to respect fundamental societal interests, such as human rights, labour standards or environmental protection, and the specific focus is on the role of contract law in regulating this corporate regulatory activity. To that end, the paper consists of four parts: it starts by proffering an explanation of why the phenomenon of corporate codes of conduct has only recently started to interest contract law scholars. It continues by analysing the way in which corporations use (and do not use) contracts and contract law enforcement in developing and practising their codes, and how contract law doctrine perceives this strategy. It reveals that there is currently a high degree of uncertainty over how contract law doctrine should react to this phenomenon. A normative argument is therefore developed and contextualised in favour of a stronger role for contract law in enforcing and regulating corporate codes. The paper concludes by emphasising the need for contract law to become regulatory in a novel sense: rather than focussing solely on the regulation of private actors via mandatory rules, contract law needs to be responsive to the conflict brought about by regulation through corporate codes of conduct by specifying clear rights and obligations that corporate regulators incur through adopting of a code of conduct.
\end{abstract}

\title{
Keywords
}

Corporate regulation, contract law doctrine, corporate codes of conduct.

I would like to thank Rob van Gestel and Hans Micklitz for valuable comments on an earlier version as well as the participants at the workshop 'contract and regulation' and the Thematic Research Group on 'Governance, Constitutionalism and Democracy' for helpful discussions on the draft. 



\section{Introduction}

Codes of conduct have become an increasingly popular response by private and public actors to specify rules of proper social, professional or ethical conduct. Individual companies develop them as internal policies for their employees and they form part of agreements in business-to-business and business-to-consumer contracts. They can appear as rules of professional conduct set by organisations for their members or for a specific industry sector. NGOs develop codes of conduct as models for businesses and, interestingly, also for their own activities. Codes of conduct are used in the public sector as well. One can find codes of conduct for government officials, codes of conduct that specify political agreements with a view to specific policy issues, or codes that serve as model rules for businesses.

Equally, the variety of topics that these codes of conduct deal with is impressive: advertising, food safety, privacy, professional conduct, workplace standards, corruption, scientific integrity or financial services, to name only a few. And yet the general private law debate, leaving aside some scholars interested in socio-legal research ${ }^{1}$ and some very recent research, ${ }^{2}$ has not really seemed to partake in this development. There appears to be an attitude of ignorance towards codes of conduct rather than active engagement in the discussion. The lack of a deeper legal debate on codes of conduct provisions in the unfair commercial practices directive on codes of conduct ${ }^{3}$ seems to be a case in point. Although the provision is formulated in quite a broad manner there remains a remarkable silence in private law scholarship and on the part of courts to give the provision a legal meaning. The types of code of conduct it should cover, the types of unfair trading behaviour that qualify a code as a breach and how this is enforced still lack a systematic evaluation. ${ }^{4}$

In the light of this lack of engagement, I seek to engage deeper in an inquiry into the relation between codes of conduct and private law, with a specific focus on contract law, and to provide:

1. an explanation of why contract law scholarship has been at unease with codes of conduct even though they have become a tool increasingly employed by public and private actors to govern their conduct, and some reasons why this is currently subject to change;

2. a descriptive analysis of how the relation between state contract law and codes of conduct can be understood, both from the perspective of those who engage in this type of self-regulation and from the perspective of contract law doctrine;

${ }^{1}$ First and foremost, G. Teubner, 'Self-constitutionalizing Transnational Corporations? On the Linkage of "Private" and "Public" Corporate Codes of Conduct' 18 Indiana Journal of Global Legal Studies, 17-38; M. Herberg, 'Global Legal Pluralism and Interlegality: Environmental Self-Regulation in Multinational Enterprises as Global Law-Making' in O. Dilling, M. Herberg and G. Winter (eds.), Responsible Business Self-Governance and Law in Transnational Economic Transactions (Hart Publishing, Oxford 2008), 17-40; L. C. Backer, 'Economic Globalization and the Rise of Efficient Systems of Global Private Law Making: Wal-Mart as Global Legislator' 39 Connecticut Law Review, 1739-84

${ }^{2}$ A. Beckers, Enforcing Corporate Social Responsibility Codes: On Global Self-Regulation and National Private Law (Hart Publishing, Oxford 2015); K. Peterkova Mitkidis, Sustainability Clauses in International Business Contracts (Dovenschmidt Monographs, Eleven International Publishing, The Hague 2015); L. Vytopil, Contractual Control in the Supply Chain. On Corporate Social Responsibility, Codes of Conduct, Contracts and (Avoiding) Liability (Eleven International Publishing, The Hague 2015); P. Verbruggen, Enforcing Transnational Private Regulation: A Comparative Analysis of Advertising and Food Safety (Edward Elgar, Cheltenham 2014); C. Glinski, Die rechtliche Bedeutung der privaten Regulierung globaler Produktionsstandards (Nomos, Baden-Baden 2011) Cf. also C. Bumke and A. Röthel (eds.), Privates Recht (Mohr Siebeck, Tübingen 2011)

${ }^{3}$ Art. 6 (2)(b) Unfair Commercial Practices Directive.

${ }^{4}$ For a notable exception, see C. Pavillon, 'The Interplay between the Unfair Commercial Practices Directive and Codes of Conduct' 5 Erasmus Law Review, 267-88 and F. Cafaggi, 'Self-Regulation in European Private Law' in A. S. Hartkamp and others (eds.), Towards a European Civil Code Fourth Revised and Expanded version (Kluwer Law International, Alphen aan den Rijn 2011), 91-126. And with a more practical outlook, A. Bochon and A. v. Waeyenberge, 'The role of codes of conduct in the assessment of unfair commercial practices' Journal of Business Law, forthcoming. 
3. a normative argument on how the relation should look, i.e. whether there is a need for private law to engage I $\mathrm{n}$ the regulation of codes of conduct;

4. a concluding interpretation of what this could imply for the distinction between contracts and regulation.

Admittedly, this suggests quite ambitious objectives. Hence, in order to be able to offer answers, a micro-focus is employed that concentrates on these questions only with a view to one specific type of code of conduct and one specific issue area. The codes of conduct that will be put under scrutiny are those of individual companies (corporate codes of conduct) that deal with aspects of corporate social responsibility (CSR), i.e. workplace standards, environmental protection, human rights or ethical aspects of businesses (corporate social responsibility codes). According to the objectives specified above, four questions guide this contribution. If, indeed, in the doctrinal private law debate these particular types of codes of conduct have in the past been widely ignored, what could be the reason for this lack of interest and, based on that, where does the renewed recent interest in corporate codes come from (Section II)? Where do corporate codes and private law interact and how is this relation perceived by those developing codes of conduct and private law (Section III)? Is there a normative justification for making codes of conduct, which are instruments of corporate selfregulation, legal obligations and how can this legalization be envisaged in its broader context (Section IV)? And what does this imply for the relation between contracts and regulation (Section V)?

The objective underlying this contribution is to deliver insights into the character of corporate codes as evolving instruments of genuine political regulation that in order to realise this regulatory purpose rely and avoid relying on contracts and their legally binding character in a strategic way. As I argue, this new form of regulation challenges different aspects of contract law and, from a normative point of view, requires contract law to pay due respect to it. More concretely, contract law is called upon to specify the duties of private regulators and substantive rules for their interaction with public law with the objective of corporations regulating themselves as private regulators and codes of conduct as the means of regulation. To this end, the general insight that I proffer is the need for contract law to become regulatory in a novel sense: rather than focussing solely on the regulation of private actors on the basis of mandatory rules, contract law needs to be responsive to the conflict brought about by regulation through corporate codes of conduct.

\section{II. "Strangers no longer": The relation between corporate codes and private law scholarship in transformation}

The starting point for this contribution on codes of conduct, contract and regulation was a statement of surprise that perhaps only legal scholars intrigued by the power of social ordering could raise. Why do scholars of contract law remain largely unaffected by developments in the 'real' world, such as the rise of self-regulation in general and codes of conduct more specifically? Why, referring to Macaulay, is law understood and taught in a way that "rested on a picture of the business world that was so distorted that it was silly"?

For corporate codes of conduct, a simple answer could be to blame the phenomenon of codes of conduct, which seem not to have existed in the past. As empirical studies suggest, corporate codes of conduct only became a major response by companies, and at the international level, in the 1990s, as a result of corporate scandals. ${ }^{6}$ One could thus infer that private law could have ignored them because if they existed at all they remained rather a marginal phenomenon. However, this perspective seems questionable when the perspective is widened to research on business ethics in general. Although not necessarily named codes of conduct, corporate commitments to formalise the ethical dimension of business already existed significantly earlier than the 1990s. Studies on business ethics already

\footnotetext{
${ }^{5}$ S. Macaulay, 'Crime and Custom in Society' 22 Journal of Law and Society, 248-58, p. 249.

${ }^{6}$ See A. Kolk and R. van Tulder, 'Setting new global rules? TNCs and Codes of Conduct' 14 Transnational Corporations, 127, p. 6.
} 
focused on codes of ethics in the 1970s; in fact, one study on corporate 'creeds' even dates back to the 1950 s. $^{7}$ Some even go as far as identifying their origin "around 1900 in response to the reforms of the late nineteenth century." ${ }^{\prime 8}$ Hence, corporate codes in the form of ethical guidelines for businesses already existed in the past.

Against this background, I proffer a slightly different answer on the absence of interest by private lawyers in engaging in a debate on corporate codes of conduct. By embedding the phenomenon of corporate codes within its national context, in particular within the functioning of a specific capitalist system, and linking it to the specifics of private law thinking in the same national context, I seek to reveal that the reason why corporate codes and private law thinking remained two worlds apart was also a matter of underlying and very implicit assumptions in private legal thought about their object of study, which excluded codes of conduct precisely because they were, in the same national context, not part of the sphere under scrutiny. This can also provide an explanation of why this situation is currently changing: it is a change in the institutional context, a transformation of capitalism, globalisation and the structure of companies, that makes corporate codes more prominent and that calls for a deeper analysis of how corporate codes and private law interact.

\section{Strangers...: National contexts of corporate social responsibility and private law}

My starting point is the observation that the engagement of companies with social, ethical or environmental concerns has evolved differently in specific national contexts. As empirical evidence suggests, express commitments by companies to engage in corporate social responsibility seem to have become significantly more common in the U.S. than in other national legal systems, in particular if compared to Continental Europe. ${ }^{9}$ Research in comparative political economy provides a potential explanation for this different development. It is specific national social institutions, emphasised prominently in the varieties of capitalism research, that have shaped how companies practise corporate social responsibility. ${ }^{10}$ An additional inquiry into the private law thinking within the same national context may then indicate why the field of corporate social responsibility had to remain a blind spot in private law thinking. To develop this argument, two different national contexts shall be examined, two that are characteristic of different variants of capitalism and consequently conceptualisations of corporate social responsibility and, moreover, different forms of private legal thought: the United States and Germany.

\section{a) United States: a state/market distinction in CSR vs. instrumental private law}

In the socio-economic model of the variants of capitalism, the United States is treated as the national context that comes closest to the ideal type of a liberal market economy. ${ }^{11}$ As such, its main characteristics are a strong focus on the competitive market as the producer of social goods combined with selective regulatory intervention by the state in order to maintain competition and sanction

\footnotetext{
${ }^{7}$ See G. C. S. Benson, 'Codes of Ethics' 8 Journal of Business Ethics, 305-19, p. 306, who refers to a study by Steward Thomson from 1958 on management 'creeds' or 'credos', which he defines as the precursor of the codes of ethics adopted in the 1970 s and 80 s.

${ }^{8}$ C. Wiley, 'The ABC's of Business Ethics: Definitions, Philosophies and Implementation' 37 Industrial Management, 22-7, p. 24.

${ }^{9}$ See, e.g., the empirical studies by C. C. Langlois and B. B. Schlegelmilch, 'Do Corporate Codes of Ethics Reflect National Character? Evidence from Europe and the United States' 21 Journal of International Business Studies, 519-39; I. Maignan and D. A. Ralston, 'Corporate Social Responsibility in Europe and the U.S.: Insights from Business' Self-Presentations' 33 ibid 497-514; Cf. also Kolk and van Tulder, 'Setting new global rules? TNCs and Codes of Conduct', p. 8; D. Matten and J. Moon, "'Implicit" and "Explicit" CSR: A Conceptual Framework for a Comparative Understanding of Corporate Social Responsibility' 33 Academy of Management Review, 404-24, p. 404.

${ }^{10}$ P. A. Hall and D. Soskice (eds.), Varieties of Capitalism: The Institutional Foundations of Comparative Advantage (Oxford University Press, Oxford 2001) . For its application in relation to corporate social responsibility, Matten and Moon, "'Implicit" and "Explicit" CSR: A Conceptual Framework for a Comparative Understanding of Corporate Social Responsibility'.

${ }^{11}$ The following characteristics are mainly taken from Hall and Soskice (eds.),
} 
market failures. Within this context, corporate social responsibility could have primarily evolved as a form of voluntary engagement by individual companies acting in the market, which is only very selectively replaced by state intervention in the form of administrative and criminal sanctions in the case of corporate scandals and market failure. ${ }^{12}$ Such an individualised system of corporate social responsibility is supported by different institutional factors, such as a financing system that is organised around the stock market with a high dispersion of shares, corporate governance oriented around an ownership-management structure and highly flexible labour and education systems. This allows short-term company orientation in reaction to market demands, but simultaneously requires companies to develop individual strategies to increase their attractiveness on the market and remain competitive. Ethical components and social benefits become an attraction for shareholders, highlyskilled employees and consumers, and hence a competitive advantage, and can even prevent the albeit weak pressures from labour and its claims for stronger protection and participation. ${ }^{13}$ Moreover, a fundamental distinction exists between the competitive market and the state, which is aksi reflected in cultural perceptions of corporate philanthropy. In general, in the national context of the United States, a strong belief in corporate stewardship of common goods is present, which reveals itself in an expectation that the individual, in particular the wealthy businessman and later corporate management, should be good citizens with a capacity and responsibility towards the community. ${ }^{14}$ Based on this understanding, corporate social responsibility strategies of companies can also be explained as individualised responses by businessmen to meet this expectation. This approach is reflected in the language and intent of CSR practice, which takes the form of active and explicit communication that is the result of an individual "deliberate, voluntary, and often strategic decision of a corporation." "15

Contrasting this understanding with the development of private legal thought within American legal thought, one may find several indications of why this explicitly practised corporate social responsibility has been below the radar of private law scholars. To be sure, if one had looked at this form of corporate social responsibility through a more 'classical' understanding of private law as the field of law dealing with private conduct in the market, one could have inferred that private law would have been competent to facilitate or regulate corporate codes of conduct. However, what is important to note is that this classical understanding was already deconstructed at an early stage. One may only recall the path-breaking work of Roscoe Pound on law as an instrument for social engineering, ${ }^{16}$ the debates in the Lochner era resulting in the rise of legal realism thinking, ${ }^{17}$ and later leftist critical and

${ }^{12}$ See instructively D. Vogel, 'The Globalization of Business Ethics: Why America Remains Distinctive' 35 California Management Review, 30-49.

${ }^{13}$ Pointedly, J. Hoffmann, 'Co-ordinated Continental European Market Economies Under Pressure From Globalisation: Germany's Rhineland Capitalism' 5 German Law Journal, 985-1002, p. 1001, fn 54: 'multinationals are (...) adopting codes of conduct or corporate social responsibility (CSR standards) as uniform, certified methods of embedding economic activity into society. In this way, they gain a certain amount of security in unstable consumer markets (threats of boycotts) and can guard against potential action by trade unions.' Cf. also on explicit corporate social responsibility as a reaction to the corporate 'defeat' of labour, R. Marens, 'Generous in victory? American managerial autonomy, labour relations and the invention of Corporate Social Responsibility' 10 Socio-Economic Review, 59-84

${ }^{14}$ See, for an overview of the conceptual debates on corporate social responsibility and its relation to philanthropy, A. Carroll, 'A History of Corporate Social Responsibility: Concepts and Practices' in A. Crane and others (eds.), The Oxford Handbook of Corporate Social Responsibility (Oxford University Press, Oxford 2008), 19-46., p. 20ff.

15 Matten and Moon, "'Implicit" and "Explicit" CSR: A Conceptual Framework for a Comparative Understanding of Corporate Social Responsibility', p. 410.

${ }^{16}$ R. Pound, 'The Scope and Purpose of Sociological Jurisprudence. Part I' 24 Harvard Law Review, 591-619; R. Pound, 'The Scope and Purpose of Sociological Jurisprudence. Part II' 25 Harvard Law Review, 140-68; R. Pound, 'The Scope and Purpose of Sociological Jurisprudence. Part III' 25 Harvard Law Review, 489-516

${ }^{17}$ Pointedly, M. J. Horwitz, 'The History of the Public/Private Distinction' 130 University of Pennsylvania Law Review, p. 1426: "Paralleling arguments then current in political economy, they [legal realists, AB] ridiculed the invisible-hand premise behind any assumption that private law could be neutral and apolitical. (...)". Cf. also for a description of American legal realism as being based on an inherently political conception of the law (and judicial activism) and a comparison with Scandinavian realism, G. S. Alexander, 'Comparing the Two Legal Realisms - American and Scandinavian' 50 American Journal of Comparative Law, 131-74. 
rightist economic legal scholarship. The result of this influential scholarship was to deconstruct the public/private divide and to perceive law, including private law, as an instrument used by the state and courts to intervene in the private (market) sphere for policy purposes. ${ }^{18}$ Private law was not a neutral or apolitical field of law that simply enforced the actions and agreements of actors in the market, but rather an instrument located in the public sphere, in politically activist courts and government regulation. If corporate social responsibility was thus economically, culturally and politically deeply enshrined in market practices and a matter of corporate philanthropy, and if it was, moreover, perceived to be of an individual rather than collective political nature, private law did not seem to be needed to stabilise, facilitate or intervene. And, vice versa, the non-intervention of private law in individual CSR practices helped justify these practices precisely in the way in which they were perceived in this capitalist system, namely as competitive private self-regulation on the market. The only issue in which private law had to intervene was determination of the place of corporate social responsibility between the market and philanthropy, as evidenced in the question of the extent to which corporate social responsibility practices by companies, perceived as voluntary corporate philanthropy, should be prohibited due to their potential to detrimentally affect the orientation of companies in the market as the core deliverers of social welfare. ${ }^{19}$

At a more abstract level, one could describe this lack of fit between private law thought and corporate social responsibility as being caused by two fundamentally different assumptions regarding the relation between the public and the private spheres: whereas the capitalist system in the United States is characterised by a strong distinction between the market and the state, with corporate social responsibility being related to the former and being of an individual nature, this very distinction was deconstructed within private legal thinking in favour of perceiving private law as instrumental and related to the sphere of collective public policy that intervenes in the market. As such, scholars inevitably had to be blind to individual and market-based corporate social responsibility practices being part of the scope of private law.

\section{b) Germany: Co-operation vs. a public/private distinction in the law}

The capitalist system in Germany is, in contrast, classified as a prototype of what in the varieties of capitalism literature is understood as a co-ordinated market economy. To that end, the leading organisational paradigm on which capitalism is built is co-operation and co-ordination through longterm relations and not a clear distinction between the market and state. Within this institutional context, corporate social responsibility evolved neither as a matter solely of individual corporations and the ordering capacity of the market nor as a matter of regulatory intervention. Instead, it was shaped by an institutional co-operation between different social interest groups which created expectations of proper socially responsible conduct. Long-term relations with house banks for financing purposes, a corporate governance structure with co-determination, i.e. participation by employees, and a historically evolved composition of shareholding that focused on the collective interest of all shareholders as part of the interest of the enterprise ${ }^{20}$ added to this institutional environment. As a result, the objectives of the firm were more strongly influenced by the long-term sustainability of the company in the light of market success, security of employment and politically defined social interest. ${ }^{21}$ Corporate social responsibility strategies were not developed individually and

18 Cf. M. Reimann, 'The American Advantage in Global Lawyering' 78 Rabels Zeitschrift für ausländisches und internationales Privatrecht, 1-36, p. 13f. (pointedly on p. 14: “(...) American jurisprudence has long openly acknowledged and usually welcomed that questions of right and wrong turn heavily on larger social goals as well as on the decisionmaker's political views").

${ }^{19}$ See, fundamentally, the seminal Berle-Dodd debate in corporate law: A. A. Berle, 'Corporate Powers as Powers in Trust' 44 Harvard Law Review, 1049-74; E. M. Dodd, 'For Whom Are Corporate Mangers Trustees?' 45 ibid 1145-63; A. A. Berle, 'For Whom Are Managers Trustees: A Note' ibid 1365-72.

${ }^{20}$ See, generally on this understanding, M. Gelter, 'Taming or Protecting the Corporation? Shareholder-Stakeholder Debates in a Comparative Light' 7 NYU Journal of Law \& Business, 641-730, p. 686ff.

21 Hoffmann, 'Co-ordinated Continental European Market Economies Under Pressure From Globalisation: Germany's Rhineland Capitalism', p. 990; W. Streeck and M. Höpner, 'Alle Macht dem Markt?' in W. Streeck and M. Höpner (eds.), 
strategically in reaction to markets or as a matter of voluntary private stewardship; instead, corporate social responsibility was inherent in the behaviour of companies complying with this institutional environment and pursuing the externally expected social objectives. This was an implicit understanding of corporate social responsibility that did not rely on corporate codes institutionally expected of companies in co-operation with the state and interest groups. ${ }^{22}$ Individual companies practice corporate social responsibility. However, these are not codified individual guidelines or commitments, but take the form of a subtle "reaction to, or reflection of, a corporation's institutional environment," of which companies do not claim authorship. ${ }^{23}$

This implicit conception of corporate social responsibility stands in contrast with the understanding of private law in the same institutional context, which rested on a much stronger and long-prevailing distinction between the public and the private spheres and their different areas of competence. In fact, the traditional understanding in legal thinking has been to treat public and private law as two separate spheres within the law, where private law was occupied with private relations and public law with matters of the state. ${ }^{24}$ A powerful narrative arose that treated private law as being based on party autonomy and freedom of contract, ${ }^{25}$ which correlated with the perceived function of private law of supporting and facilitating individual self-determination in its relations with others and of public law of being instrumental to intervene in this private sphere for policy purposes. The influential ordoliberal understanding seems paradigmatic of this perception. ${ }^{26}$ According to this understanding, the private sphere was defined as private law society (Privatrechtsgesellschaft), as a social sphere governed by private law that effectively rested on institutions, such as freedom of contract and private property, that were guaranteed in public law in the form of an 'economic constitution'. To be sure, there were debates on the soziale Frage in private law ${ }^{27}$ and later on the intellectual influence of the American debate between instrumental and political private law. ${ }^{28}$ Nonetheless, these tendencies remained strongly associated with a need to preserve the integrity of private law as a formalist market-based area by treating such elements of social protection as special private laws and regulations (Sonderprivatrecht). ${ }^{29}$ Any instrumentalist version of private law occupied a 'specific' status that was separate from general private law. This perception contributed to

(Contd.)

Alle Macht dem Markt? Fallstudien zur Abwicklung der Deutschland AG (Campus, Frankfurt/New York 2003), 11-59, p. $11,14$.

${ }^{22}$ Matten and Moon, "'Implicit" and "Explicit" CSR: A Conceptual Framework for a Comparative Understanding of Corporate Social Responsibility', p. 409-10.

${ }^{23}$ Ibid., p. 410. Cf. also S. Hiß, 'From Implicit to Explicit Corporate Social Responsibility: Institutional Change as a Fight for Myths' 19 Business Ethics Quarterly, 433-51, p. 436: "Corporations had almost no need to practice voluntary CSR outside mandatory issues. In the context of this national setting, it was the existing institutions that were able to bind corporations to socially responsible behaviour."

${ }^{24}$ F. C. v. Savigny, System des heutigen römischen Rechts (Bei Veit und Comp., Berlin 1840), vol I, p. 22: 'Übersehen wir von dem nun gewonnenen Standpunkt aus das Recht, so unterscheiden wir in demselben zwei Gebiete, das Staatsrecht und das Privatrecht. Das erste hat zum Gegenstand den Staat, das heißt die organische Erscheinung des Volks: das zweite die Gesamtheit der Rechtsverhältnisse, welche den Einzelnen umgeben, damit er in ihnen sein inneres Leben führe und zu einer bestimmten Gestalt bilde.'

${ }^{25}$ See, for an impressive theoretical analysis of freedom as the powerful narrative for private law scholarship, M. Auer, Der privatrechtliche Diskurs der Moderne (Mohr Siebeck, Tübingen 2014).

${ }^{26}$ F. Böhm, 'Privatrechtsgesellschaft und Marktwirtschaft' in F. Böhm (ed.), Freiheit und Ordnung in der Marktwirtschaft (Nomos, Baden-Baden 1966), 105-68

${ }^{27}$ Fundamentally, O. v. Gierke, Die soziale Aufgabe des Privatrechts: Vortrag gehalten am 5. April 1889 in der juristischen Gesellschaft zu Wien (Verlag Julius von Springer, Berlin 1889). Cf. also later L. Raiser, Die Zukunft des Privatrechts (Walter de Gruyter, Berlin/New York 1971).

${ }^{28}$ One may in particular refer here to the German political school in private law and the influences on it in particular of critical legal thought. Cf. C. Joerges and D. M. Trubek (eds.), Critical Legal Thought: An American-German Debate (Nomos, Baden-Baden 1989)

${ }^{29}$ See, H. Micklitz, 'Introduction' in H. Micklitz (ed.), The Many Concepts of Social Justice in European Private Law (Edward Elgar Publishing, Cheltenham 2011), 3-60, p. 20-22. 
upholding the distinction within private law thinking between private law freedom and interventionist state regulation, between liberalism and authority, as two opposing strands. ${ }^{30}$

Relating this understanding to the above-discussed evolution of corporate social responsibility, co-operation between interest groups as a way to determine the rules for socially responsible conduct and to shape the implicit practice of individual companies was not a matter of the private sphere of the market and thus not a matter of private law. Corporate responses to institutionalised expectations of interest groups were not a voluntary and individual behaviour in the market, which is precisely the type of behaviour that in private law thought was considered to be the core competence of private law. And, as in the U.S. context, one could argue at an abstract level that it is the continuing existence of the analytical distinction within private law thinking between the spheres of the state and the market as separate competences of private law and public law respectively which did not fit with corporate social responsibility as a practice that resisted any classification into either private or public. Corporate social responsibility was a mode of institutional co-operation between public and private actors that companies had to comply with without subjecting it explicitly to their market conduct, which private law considered itself responsible for.

\section{2. ...no longer: An evolving role for private law in corporate codes?}

Given this past institutional divergence in the relation between private law and corporate social responsibility and related corporate behaviour, how is it possible that this relation has recently been transformed? Why have private law scholars started to show an interest in corporate social responsibility codes as an object of study? ${ }^{31}$ I would like to put emphasis on three important drivers that relate primarily to changes in the institutional environment shaping corporate behaviour (and thus corporate codes). These are: 1) an institutional change of national forms of capitalism; 2) the role of codes of conduct given the transformation of companies from domestic legally incorporated entities into transnational corporations; and 3) a change in the understanding of what corporate social responsibility substantively entails.

\section{Institutional changes}

The first important driver of a stronger interaction can be derived from the arguments made above. If private law and corporate social responsibility were two worlds apart in their national institutional contexts, one can assume that this situation is likely to change in a situation of institutional transformation. Arguably, such a trend can currently be observed. Companies that have been firmly embedded in a co-ordinated market economy seem to reconcile their global strategies with demands from liberal market economies, leading to what scholars have labelled hybridisation. ${ }^{32}$ The drivers of such changes seem to come from within the national context (internal political changes towards liberalization) as well as outside of it (Europeanization and globalization) ${ }^{33}$ In this situation, explicit forms of corporate social responsibility, i.e. voluntary and strategic codes of conduct, become necessary measures to operate in a different national context, for instance meeting the disclosure requirements necessary to be listed on American Stock exchanges or meeting consumer demands. ${ }^{34}$

${ }^{30}$ H. Micklitz, 'On the Intellectual History of Freedom of Contract and Regulation' 4 Penn State Journal of Law \& International Affairs, 1-32, p. $21 \mathrm{ff}$.

${ }^{31}$ For this interest, see the references in n. 2.

32 See, with manifold empirical evidence, M. Höpner, Wer beherrscht die Unternehmen? Shareholder Value, Managerherrschaft und Mitbestimmung in Deutschland (Campus Verlag, Frankfurt am Main 2003). Cf. also Hoffmann, 'Co-ordinated Continental European Market Economies Under Pressure From Globalisation: Germany's Rhineland Capitalism'.

${ }^{33} \mathrm{Hiß}$, 'From Implicit to Explicit Corporate Social Responsibility: Institutional Change as a Fight for Myths', p. $436 f$.

${ }^{34}$ Important disclosure laws applicable to European companies have been, for instance, introduced through the U.S. Sarbanes-Oxley Act, specifically s. 402, 406 Sarbanes-Oxley Act, which requires companies to have in place a 'code of ethics' for their internal operations. It is incorporated in the listing rules of the New York Stock Exchange and thus also covers non-U.S. companies to the extent they are listed on the NYSE. See s. 303A.10, New York Stock Exchange Listed Company Manual: 'Listed companies must adopt and disclose a code of business conduct and ethics for directors, 
Moreover, explicit corporate social responsibility can become a tool for companies to redefine their role at home by advocating a voluntary understanding of corporate social responsibility in an unstable and gradually changing institutional context. This can be observed in the German context, where the dissolution of co-operative structures in corporate governance has led to a stronger emphasis on corporate self-regulation and codes of conduct as a means of regulation. ${ }^{35}$ It is also a trend that fits with the debate at the EU level. In the absence of a clear definition of corporate social responsibility, the political debate starting from the Green Paper in $2001^{36}$ was strongly influenced by business, which directed it towards placing the emphasis on self-regulation and codes of conduct. ${ }^{37}$ This suggests that at least in the continental European systems, it is institutional change that led to a situation in which explicit market-oriented social responsibility became a practice within co-ordinated market economies, which can open the door for private law and its focus on the regulation of individual market behaviour. ${ }^{38}$

\section{Transnationalisation}

A second important development resulting in a stronger interaction lies in the changing institutional context of globalization and the related transformation of companies. The increasing cross-border operation and foreign investment strategies of companies have resulted in a situation where the question of corporate social responsibility is not only pressing within different national contexts, but also a matter of global governance. ${ }^{39}$ Due to the governance gap at a global level, corporate codes have become a tool with which companies seek to substitute a missing global government by setting their standards autonomously, which is also furthered by attempts in the international community to develop soft law in the form of codes of conduct rather than enacting treaties to impose direct obligations on private actors. ${ }^{40}$ Due to the constraints of the Westphalian system of international law, private law has received attention because of several comparative advantages that it has in order to grasp this new 'public' function of companies. Whereas international law focuses on states as its main

(Contd.)

officers and employees, and promptly disclose any waivers of the code for directors or executive officers.' Furthermore, it is discussed (although still subject to controversy) whether information duties on CSR practices towards consumers may derive from unfair commercial practices law. Cf. with further reference to the debate A. Birk, 'Irreführung über CSR - Informationspflichten über CSR?' in R. Hilty and F. Henning-Bodewig (eds.), Corporate Social Responsibility Verbindliche Standards des Wettbewerbsrechts? (Springer, Berlin / Heidelberg 2014), 169-86, p. $176 \mathrm{ff}$.

${ }^{35} \mathrm{Hiß}$, 'From Implicit to Explicit Corporate Social Responsibility: Institutional Change as a Fight for Myths', p. 438ff., who describes this as a 'fight for myths'.

${ }^{36}$ European Commission, Green Paper, Promoting a European Framework for Corporate Social Responsibility COM (2001) 366 final, p. 6, where the Commission declares that 'Most definitions of corporate social responsibility describe it as a concept whereby companies integrate social and environmental concerns in their business operations and in their interaction with their stakeholders on a voluntary basis' (Emphasis added) and adopts this as its own definition.

${ }^{37}$ See, extensively on the policy debates in reaching this European understanding of CSR, O. De Schutter, 'Corporate Social Responsibility European Style' 14 European Law Journal, 203-36. Arguably, this strong focus on self-regulation and voluntary CSR was not significantly changed by the 'renewed' strategy of the Commission in 2011. Despite accepting a regulatory dimension of CSR through EU laws, this strategy still places the emphasis on the fact that the 'development of CSR should be led by enterprises themselves' (European Commission, A renewed EU strategy 2011-14 for Corporate Social Responsibility, COM (2011) 681, p. 7).

${ }^{38}$ See, for the argument supporting a stronger readiness of private law in co-ordinated market economies to enforce corporate codes of conduct, G. Teubner, 'Corporate Codes in the Varieties of Capitalism: How their Enforcement Depends Upon the Difference Between Production Regimes' 23 Indiana Journal of Global Legal Studies, forthcoming.

${ }^{39}$ Beckers, Enforcing CSR Codes, p. $9 \mathrm{ff}$.

${ }^{40}$ See, e.g., the Draft United Nations Code of Conduct on Transnational Corporations, UN Doc. E/C.10/1982/6, 5 June 1982 (revised UN Doc. E/1983/17/Rev.1); the OECD Guidelines for Multinational Enterprises 1976 (last update 2011); UN Guiding Principles on Business and Human Rights 2011 (A/HRC/17/31) endorsed by the UN Human Rights Council on 6 July 2011 (A/HRC/RES/17/4). 
subjects and thus their capability to regulate corporations, private law can play an important role due to its character of regulating the conduct of private actors directly. ${ }^{41}$

Another related element is the reorganisation of companies from previously hierarchical organisations into a fragmented system that includes subsidiaries as parts of corporate groups and suppliers and distributors as parts of contractual networks. ${ }^{42}$ Under these conditions, corporate codes fill a gap by not being restricted to the regulation of one single corporation, but by extending the scope of application of the code of conduct to the entire corporate group including - via contracts - the worldwide operating network of suppliers and distributors. Again, this novel use of codes of conduct within specifically transnational corporations as tools to regulate contractual relations through the supply chain across national borders can specifically call upon private law to regulate itself.

\section{A broader focus of CSR in substance}

Finally, under globalization companies have become confronted with societal demands that go beyond the responsibility for labour, consumers or shareholders that they have faced in the national context as a result of the expectations of either the market or the corporatist institutional environment. Due to, amongst other things, pressures from non-governmental organisations or recommendations by politicians, companies are expected to pay respect to ethical business conduct by preventing corruption, internalising the ecological dimension in their business behaviour, and protecting the human rights of individuals and the respect rights of local communities. These are issues that have become what some authors describe as genuine global problems or risks, ${ }^{43}$ for which no clearly defined distribution of competences exists within global capitalist structures between the public and the private sphere. It is this institutional uncertainty which companies have already stepped into with their corporate codes. As one observer has it, 'Corporate codes no longer only mediate the distributive interests of capital and labour within the enterprise. The civil society protests go much further than these important but limited themes, and compel corporations to establish encompassing public interests with binding force: environmental protection, anti-discrimination, human rights, product quality, consumer protection, data protection, freedom of the internet, and fair trade. ${ }^{44}$ This voluntary assumption of responsibility by companies for factors that have not traditionally been part of corporate responsibilities in the national context could, in turn, open space for private lawyers precisely because they have no clear institutionalised competence between the state, corporations and stakeholders. After all, these efforts have their origin in truly private (corporate) conduct. Simultaneously, these new efforts are not yet institutionalised within the capitalist structure as a competence of the state, market or co-operation between interest groups, which opens up room for experimentation and debate on whether private law is or should be competent to deal with these new self-regulatory corporate responsibilities. The evolving debate on how to deal with the new contracting between companies on human rights may be but one prominent example of where such a new discussion can take place. ${ }^{45}$

${ }^{41}$ Cf. for this 'state-making' function of private law under globalization: D. Caruso, 'Private Law and State-Making in the Age of Globalization' 39 New York University Journal of International Law and Politics, 1-74.

${ }^{42}$ See, in detail Beckers, Enforcing CSR Codes, p. $11 \mathrm{ff}$.

${ }^{43}$ R. Michaels, 'Global Problems in Domestic Courts' in S. Muller and others (eds.), The Law of the Future and the Future of Law (Torkel Opsahl Academic EPublisher, Oslo 2011), 165-75, p. 166ff.; A. G. Scherer and G. Palazzo, 'Globalization and Corporate Social Responsibility' in A. Crane and others (eds.), The Oxford Handbook of Corporate Social Responsibility (Oxford University Press, Oxford 2008), 413-31, p. 418-19 ('emergence of transnational risks').

${ }^{44}$ Teubner, 'Corporate Codes in the Varieties of Capitalism: How their Enforcement Depends Upon the Difference Between Production Regimes', forthcoming, MS, p. 11.

${ }^{45}$ See, e.g., F. Marrella, 'Human Rights, Arbitration, and Corporate Social Responsibility in the Law of International Trade' in W. Benedek, K. de Feyter and F. Marrella (eds.), Economic Globalisation and Human Rights (Cambridge University Press, Cambridge 2007), 266-310, p. 305, and, very recently, J. G. Ruggie and J. F. Sherman, 'Adding Human Rights to the New Lex Mercatoria: The Impact of the UN Guiding Principles on Business and Human Rights on Commercial Legal Practice' 6 Journal of International Dispute Settlement, 455-61. 


\section{The interaction between corporate codes and contract law}

Having discussed the reasons why corporate social responsibility codes have become a matter to be debated by private law scholars, I will address the question of how the two meet. In this respect, I focus specifically on the area contract law and I approach the interaction between contract law and corporate codes separately from both perspectives, namely the way in which codes of conduct perceive and (do not) use contract law in their corporate code practice and how from the contract law perspective codes of conduct would be approached. ${ }^{46}$

\section{Contract law in codes of conduct}

A general observation on the use of contract law by corporate codes is that they 'play' with the form of contracts and thus the consequence of using contract law enforcement. When looking at corporate codes of conduct in general, contracts are not a preferred form. In fact, the situation resembles what Macaulay has observed in his studies of contract practice. ${ }^{47}$ The legal dimension plays at best a marginal role for companies when developing and communicating their codes of conduct. When considering the existing studies on the motives of companies to adopt corporate codes, it becomes clear that they mainly serve other purposes. They are, in the first place, attempts by companies to strategically place themselves in the market and potentially receive a competitive advantage in attracting customers and employees. ${ }^{48}$ Moreover, sociological studies suggest that in particular large companies make the effort to go beyond compliance and publish their social and environmental commitments for the sake of meeting institutionalised expectations and maintaining what the authors of a study frame as the 'social license to operate'. ${ }^{49}$ This motive also becomes apparent from the texts of the codes, which as justification refer to the expectations of society and the need to conduct business in a sustainable manner. ${ }^{50}$ Consequently, from the sociological perspective corporate codes present themselves as a way in which companies strategically internalise social expectations coming from the market or interest groups. ${ }^{51}$ Hence, quite similarly to what Macaulay has identified in contract practice between businessmen, it is the need to create a sustainable relation (through corporate codes towards society) that seems to be more important than any legal implications. Moreover, when companies adopt a code of conduct one can frequently find a deliberate choice to not bring the law into the code, which one can see in the preference of companies to choose a unilateral declaration as the form, ${ }^{52}$ to incorporate disclaimers ${ }^{53}$ and to place emphasis on the fact that adopting a

\footnotetext{
${ }^{46}$ See, for a similar approach framing this relation, K. Webb and A. Morrison, 'The Law and Voluntary Codes: Exploring the 'Tangled Web" in K. Webb (ed.), Voluntary Codes, Private Governance, the Public Interest and Innovation (Carleton University Research Unit for Innovation, Science and the Environment, Ottawa 2004), 97-174, p. 97-102.

${ }^{47}$ See S. Macaulay, 'Non-Contractual Relations in Business: A Preliminary Study' 28 American Sociological Review, 55-67.

${ }^{48}$ J. Diller, 'A social conscience in the global marketplace? Labour dimensions of codes of conduct, social labelling and investor initiatives' 138 International Labour Review, 99-129, p. 101; M. Kerr, R. Janda and C. Pitts, Corporate Social Responsibility. A Legal Analysis (LexisNexis Canada, Markham 2009), p. 330f.; F. Cafaggi and A. Randa, 'Public and Private Regulation: Mapping the Labyrinth' 1 The Dovenschmidt Quarterly, 16-33, p. 19.

${ }^{49}$ N. Gunningham, R. A. Kagan and D. Thornton, 'Social License and Environmental Protection: Why Businessses Go Beyond Compliance' 29 Law \& Social Inquiry, 307-41; N. Gunningham, D. Thornton and R. A. Kagan, 'Motivating Management: Corporate Compliance and Environmental Protection' 27 Law and Policy, 289-316; N. Gunningham, 'Corporate environmental responsibility: law and the limits of voluntarism' in D. McBarnet, A. Voiculescu and T. Campbell (eds.), The New Corporate Accountability: Corporate Responsiblity and the Law (Cambridge University Press, Cambridge 2007), 476-500.

${ }^{50}$ For a detailed analysis of codes of conduct in the chemical industry M. Herberg, Globalisierung und private Selbstregulierung. Umweltschutz in multinationalen Unternehmen (Campus, Frankfurt am Main 2007), p. 77ff.

${ }^{51}$ See, fundamentally, S. Hiß, Warum übernehmen Unternehmen gesellschaftliche Verantwortung? (Campus, Frankfurt/New York 2005).

${ }^{52}$ Herberg, 'Global Legal Pluralism and Interlegality: Environmental Self-Regulation in Multinational Enterprises as Global Law-Making', p. 25.
} 
code of conduct is a 'moral obligation'. The code of conduct of Volkswagen is a case in point. The company itself introduces and describes its code of conduct as follows: 'The Volkswagen Group has always considered itself bound by more than just legal and internal regulations. We also see voluntary commitments and ethical principles as an integral component of our corporate culture, providing a frame of reference we can use to guide our decision-making'. ${ }^{54}$ This seems to suggest that, from the perspective of codes, there is an attitude of avoiding 'bringing in the law' and instead opting for an autonomous basis for validity. On this basis, one could describe the relationship between the law and corporate codes from the perspective of the latter as one of ignorance or even avoidance, as a form of 'other regulation'.

However, arguably, this ignorance of the law in corporate codes is an observation that is not valid on an overall scale. Looking more closely into the functioning of codes of conduct within corporate practice, one may also identify a slight shift towards them being more strongly influenced by contract law. Companies take the commitments in their corporate code strategies seriously by beginning to control their global operations through socially acceptable conduct and this is based on an increasing interaction between corporate codes and specifically contract law. Companies are more frequently making use of the instrument of the legally binding contract in order to ensure that their corporate codes work effectively throughout the supply chain. They incorporate these codes in their contracts with suppliers ${ }^{56}$ and, in so doing, actively rely on contract law as a means of potentially enforcing their obligations towards their suppliers. Similarly, codes of conduct are made binding for employees. ${ }^{57}$ However, what is interesting to note is that in using contract law for the regulation of their global supply chains and towards their employees, companies seem to remain highly strategic in relation to the type of obligations and legal enforcement they choose. First, contracts and their legal enforcement are not used to bind themselves, as they do this in their codes through a voluntary commitment; rather, by using a specific contract design, companies seek to oblige their business partners to comply with their code. ${ }^{58}$ The same applies to employees, where the obligation to comply

(Contd.)

53 See, on disclaimers in codes of conduct if they are contractually incorporated, A. Rühmkorf, Corporate Social Responsibility, Private Law and Global Supply Chains (Edward Elgar, Cheltenham 2015), p. 104-107; J. Phillips and S.J. Lim, 'Their Brothers' Keeper: Global Buyers and the Legal Duty to Protect Suppliers' Employees' 61 Rutgers Law Review, 333-79, p. 374, 376f. On general company strategies to avoid legal liability for their codes through specific wording and contract design, see Vytopil, Contractual Control in the Supply Chain. On Corporate Social Responsibility, Codes of Conduct, Contracts and (Avoiding) Liability, p. $267 \mathrm{ff}$. On disclaimers in unilateral codes of conduct and framework agreements, see E. Kocher, 'Codes of Conduct and Framework Agreements on Social Minimum Standards Private Regulation?' in O. Dilling, M. Herberg and G. Winter (eds.), Responsible Business Self-Governance and Law in Transnational Economic Transactions (Hart Publishing, Oxford 2008), 67-86, p. 71 and Glinski, Die rechtliche Bedeutung, p. 178f. (regarding codes of conduct in advertisement campaigns towards consumers).

${ }^{54} \mathrm{http}: / /$ www.volkswagenag.com/content/vwcorp/content/en/the_group/compliance.html (emphasis added).

${ }^{55}$ For this notion, regarding contractually incorporated codes of conduct, see D. McBarnet and M. Kurkchiyan, 'Corporate Social Responsibility through Contractual Control? Global Supply Chains and 'Other Regulation" in D. McBarnet, A. Vioiculescu and T. Campbell (eds.), The New Corporate Accountability Corporate Social Responsibility and the Law (Cambridge University Press, Cambridge 2007), 59-92.

${ }^{56}$ See for empirical evidence on this phenomenon with a view to different countries and sectors, e.g., M. P. Vandenbergh, 'The New Wal-Mart Effect: The Role of Private Contracting in Global Governance' 54 UCLA Law Review, 913-70; ; L. C. Backer, 'Multinational Corporations as Objects and Sources of Transnational Regulation' 14 ILSA Journal for International \& Comparative Law, 499-523; F. Cafaggi, 'The Regulatory Functions of Transnational Commercial Contracts: New Architectures' 36 Fordham International Law Journal, 1557-618; Vytopil, Contractual Control in the Supply Chain. On Corporate Social Responsibility, Codes of Conduct, Contracts and (Avoiding) Liability; Peterkova Mitkidis, Sustainability Clauses in International Business Contracts.

${ }^{57}$ On this, see extensively D. Klösel, Compliance-Richtlinien. Zum Funktionswandel des Zivilrechts im Gewährleistungsstaat (Nomos, Baden-Baden 2012), with examples of 'ideal typical' codes of conduct that are made binding towards employees with references to codes of conduct actually used by companies, p. $194 \mathrm{ff}$.

${ }^{58}$ Backer, 'Multinational Corporations as Objects and Sources', p. 511, 518, 522; Cafaggi, 'The Regulatory Functions', p. 1592: 'Rarely does the contract wording define and impose obligations on the main contractor or the retailer to monitor compliance in the interest of the final beneficiaries'; Vytopil, Contractual Control in the Supply Chain. On Corporate Social Responsibility, Codes of Conduct, Contracts and (Avoiding) Liability, p. 268 ('(...) the instruments studied do not 
with the code is included as an obligation for them in the employment contract. Second, the perceived value of actually enforcing these formalised codes of conduct is similar to what Macaulay has observed for contractual relations between businessmen in general. An observation by McBarnet and Kurkchiyan on the basis of interviews seems revealing in this respect: 'Despite the insistence by one interviewee that contractual obligation is important to get the issues taken seriously, he was quick to add "even though it is unlikely that we would ever go to court." ${ }^{59}$ Regarding the strategic incorporation of corporate codes into contracts, one can thus describe the relation between corporate codes and contract law as one where corporate codes begin to make use of the form of the contract and its capacity to be enforced under contract law, but with a simultaneous reluctance in practice to make use of judicial enforcement.

In both the strategic use of contracts to impose standards on suppliers and employees and the strategic avoidance of relying on the form of contracts for the code of conduct, a second interesting element in the interaction between corporate codes and contract law can be observed. They are characterised by a novel purpose for private instruments - i.e. codes and contracts - to be used for: companies have started to use corporate codes as a specific means to substitute or complement public law standards. The inclination of companies to adopt and implement a corporate code throughout their global operations seems to correlate with the institutional environment of the countries in which the company and its subsidiaries are operating, as recent studies reveal. To be more precise, these studies suggest that the weaker the rule of law in general and labour and environmental laws specifically, the more a company sourcing from or investing in a country seems eager to engage in corporate social responsibility that is aimed at safeguarding minimum standards..$^{60}$ In this regard, the adoption of corporate codes is, from the perspective of corporate managers, understood as a way to substitute regulation by law ${ }^{61}$ and to act as an enforcer of weakly enforced national law, which is evidenced in the fact that the codes often contain reference to compliance with national laws and regulations in the country of operation. ${ }^{62}$ Moreover, it is a common reaction of companies to use international soft law frameworks as inspiration when designing their codes. ${ }^{63}$ This suggests that corporate codes also use contract law to harden international soft law standards and complement international hard law through incorporation into contracts. ${ }^{64}$ Finally, corporate codes also tend to reflect national legal standards concerning labour or the environment as a minimum, in the same way that that they are themselves regulated in their home country. ${ }^{65}$ In addition to this referencing to public law frameworks, however, companies also include in their codes of conduct autonomous standards that do not reflect international standards. This autonomous standard-setting seems of particular importance in the field of environmental protection, such as reducing carbon emissions, given the political controversy and the large differences in national environmental standards on this topic. Corporate codes of conduct

(Contd.)

include clear, strong obligations for the MNC [Multinational Corporation] (rather than the supplier) that would give rise to a claim if these obligations would not be lived up to').

${ }^{59}$ McBarnet and Kurkchiyan, 'CSR through Contractual Control?', p. 79.

${ }^{60}$ N. Rathert, Why and How Firms Adress Stakeholde Issues: Institutional and Organizational Determinants of Corporate Social Responsibility Action (Dissertation Free University Berlin, Berlin 2015), p. 4f.

${ }^{61}$ G. Jackson, 'A Socio-Political Perspective on Corporate Social Responsibility: Understanding Regulatory Substitution and the Persistence of Irresponsibility' in R. Hilty and F. Henning-Bodewig (eds.), Corporate Social Responsibility Verbindliche Standards des Wettbewerbsrechts? (Berlin / Heidelberg 2014), 19-31, p. 28-29.

${ }^{62}$ See McBarnet and Kurkchiyan, 'CSR through Contractual Control?', p. 66f.

${ }^{63}$ European Commission, An Analysis of Policy References made by large EU Companies to Internationally Recognised CSR Guidelines and Principles, March 2013, p. 7. Moreover, see the empirical studies by Kocher, 'Codes of Conduct and Framework Agreements on Social Minimum Standards - Private Regulation?', p. 70; L. Vytopil, 'Contractual Control and Labour-Related CSR Norms in the Supply Chain: Dutch Best Practices' 8 Utrecht Law Review, 155-69, p. 166.

${ }^{64}$ F. Cafaggi, 'New Foundations of Transnational Private Regulation' 38 Journal of Law and Society, 20-49, p. 42f. Cf. also Backer, 'Multinational Corporations as Objects and Sources', p. 522 (regarding specifically the ILO core labour standards).

${ }^{65}$ L.-W. Lin, 'Legal Transplants through Private Contracting: Codes of Vendor Conduct in Global Supply Chains as Example' 57 American Journal of Comparative Law, 711-44. 
specifying a commitment to pursue carbon emission reduction and their implementation in supplier contracts appears as an autonomous response by companies in reaction to social pressures due to the lack of a common international standard. ${ }^{66}$

Hence, one can describe corporate codes of conduct as instruments that use contracts and the power of contract enforcement through contract law strategically and selectively to complement or even substitute public law and regulation. This specific use of contracts to further public goals is important from a conceptual perspective because it changes the character of the public law norms referred to. They are not imposed on companies as obligations. Public law rather takes the form of 'norms that have no legal effect, except, ironically, as enacted into the contractual relations'. ${ }^{67}$ Public law and regulation itself appears from the perspective of companies as a matter of choice, as sets of dispositive rules that companies can voluntarily make part of their contracts and that company lawyers can advise their corporate clients to consider as possible frameworks when drafting their codes. ${ }^{68}$

\section{Corporate codes in contract law}

Reversing the perspective, what does this strategic and selective engagement in contract law in codes of conduct mean for their treatment under contract law? More specifically, does contract law doctrine ignore, accept, prohibit or itself regulate this strategic corporate behaviour? In the following, I describe the approach within contract law as being characterised by an internal conflict within contract law between different potentially applicable doctrines, and, as a result, as currently being characterised by a high degree of uncertainty as to the appropriate role of law. This conflict reveals itself primarily in the academic debate, thus contract law scholarship, but it can also be observed from the few court rulings that exist on corporate codes. I illustrate this conflict and uncertainty with respect to two aspects: 1) the aforementioned form of codes and the ambiguous shifting of companies between using contracts (without judicial enforcement) and unilateral commitments; and 2) the purpose of codes as defined by companies with a mixture of references to national laws, international soft law and the specification of autonomous standards and their general character as regulatory instruments that contain elements of private choice and public elements.

There are two aspects that I will not specifically discuss in the inquiry. First, I will not inquire into the problem of the vague content of codes of conduct, the reason for this being the conviction that contract law is capable of dealing with this problem in the course of contract interpretation. ${ }^{69}$ Second, I will not inquire into the certainly also important aspect of the transnational character of codes and the related question of the forum and the law applicable to corporate codes when they are brought under contract law. The reason for excluding this aspect relates to the fact that it would open a debate that would require going far beyond the relation between corporate codes and contract law by including the rules on jurisdiction and choice of law. Moreover, in practical terms, authors inquiring into codes of conduct under contract law have concluded that due to the choice of law in (supplier) contracts and the use of the unilateral commitment in the consumer market, it is possible to argue for the relevance of

\footnotetext{
${ }^{66}$ See, generally on this gap-filling function of (contractually incorporated) codes of conduct, in the field of environmental law, K. Peterkova Mitkidis, 'Using Private Contracts for Climate Change Mitigation' 2 Groningen Journal of International Law, 52-77.

${ }^{67}$ Backer, 'Multinational Corporations as Objects and Sources', p. 522 (regarding the ILO core labour rights). Cf. for this point also Cafaggi, 'The Regulatory Functions', p. 1565: 'Commercial contracts expand the effect of international public regulation to relationships between private parties and may increase their effectiveness by using private law as an enforcement mechanism.'

${ }^{68}$ See, for a strong case in this direction, Ruggie and Sherman, 'Adding Human Rights to the New Lex Mercatoria: The Impact of the UN Guiding Principles on Business and Human Rights on Commercial Legal Practice'

${ }^{69}$ I have elaborated more extensively on this problem of vagueness from the perspective of contract law. See, Beckers, Enforcing CSR Codes, p. 243-246, 266f. (text accompanying n. 181).
} 
the contract law of the home state of the company that has adopted the code of conduct and incorporated it into contracts. ${ }^{70}$

\section{a) Form}

Companies deliberately communicate their codes as unilateral declarations to the public and strategically incorporate them into contracts in order to bind their business partners in supply-chains and their employees internally. As unilateral acts, corporate codes conflict with the underlying principle that enforceable obligations need to be reciprocal, which renders it difficult for contract law to determine whether these codes become legal obligations. In the strategic reliance on contracts and contract law enforcement through incorporation into contracts, questions arise as to the principles underlying the interpretation of these contracts between the intention expressed in the contract, the legitimate expectations of the addresses, and the principle of contractual fairness as expressed in principles of fair dealing and good faith.

\section{(1) Unilateral declarations and the contract law principle of reciprocity}

Towards the outside world, corporate codes remain a unilateral act having the character of a selfcommitment. Companies publish their corporate codes on websites, ${ }^{71}$ they refer to them in marketing campaigns, or they put emphasis on such commitments after the company or sector has been involved in a scandal. ${ }^{72}$ This is difficult to classify from the perspective of contract law because unilateral declarations are generally not enforceable if they do not meet high formal threshold requirements. ${ }^{73} \mathrm{At}$ the heart of this interpretation lies the narrow focus within contract law on a reciprocal social interaction between private actors as the basis for legal obligations. Enforceable legal obligations are primarily those that private actors have mutually agreed upon and not those that one actor unilaterally declares.

However, it is equally true that there are certain categories that have been used to give unilateral declarations a binding character. Without neglecting the differences in detail, one may refer here to the doctrine of unilateral contracts in English law, ${ }^{74}$ the statutory exceptions in the German civil code and the case law on declarations of intent where acceptance requirements are waived ${ }^{75}$ the doctrine of promissory estoppel under U.S. law, ${ }^{76}$ or the principle of estoppel and the protection of legitimate expectations as applied in international trade. ${ }^{77}$ These narrowly confined doctrinal concepts could be used to treat these unilateral declarations as binding, but it seems to be highly contested whether they can be applied in this particular constellation. In this respect, it still seems the prevailing

\footnotetext{
${ }^{70}$ See Vytopil, Contractual Control in the Supply Chain. On Corporate Social Responsibility, Codes of Conduct, Contracts and (Avoiding) Liability, p. 43 ff.; Rühmkorf, Corporate Social Responsibility, Private Law and Global Supply Chains, p. $83 \mathrm{ff}$.

${ }^{71}$ For empirical evidence, see, e.g., K. Bondy, D. Matten and J. Moon, 'The Adoption of Voluntary Codes in MNCs: A Three-Country Comparative Study' 109 Business and Society Review, 449-77.

${ }^{72}$ See, for an illustrative example, the campaign by Chevron after the Deep Water Horizon catastrophe as described by M. A. Cherry and J. F. Sneirson, 'Chevron, Greenwashing, and the Myth of "Green Oil Companies"' 3 Washington \& Lee Journal of Energy, Climate and the Environment, 133-54.

${ }^{73}$ See, extensively on the German and English rules on contract formation, Beckers, Enforcing CSR Codes p. 81ff., 146f.; and regarding the Dutch, English and Californian system, see Vytopil, Contractual Control in the Supply Chain. On Corporate Social Responsibility, Codes of Conduct, Contracts and (Avoiding) Liability, p. 73ff. (Netherlands), p. 89 (England), p. 105.

${ }^{74}$ Fundamentally Carlill v Carbolic Smoke Ball Corp. [1892] EWCA Civ 1; Bowerman v Association of British Travel Agents [1996] CLC 451.

${ }^{75}$ On these categories, see G. Bachmann, Private Ordnung (Mohr Siebeck, Tübingen 2006), p. 227-298.

${ }^{76}$ s. 90 Restatement (Second) of Contracts.

${ }^{77}$ On this and its relevance in relation to codes of conduct, see Marrella, 'Human Rights, Arbitration, and Corporate Social Responsibility in the Law of International Trade', p. 302.
} 
opinion within the doctrinal debate that corporate codes should be treated as not enforceable, ${ }^{78}$ but there are a few authors arguing in favour of treating the unilateral act as legally binding under contract law on the basis of these doctrines. ${ }^{79}$

Interestingly enough, the case law too seems equally non-uniform on this issue. Whereas corporate codes of conduct are not considered binding in general, courts occasionally seem prepared to consider them binding if they are addressed towards actors that receive particular legal protection. To be more concrete, there is a distinction between the binding effects towards employees, consumers, business partners and the ultimate beneficiaries, such as employees in supplier factories or local communities.

In relation to employees, courts have been prepared to interpret unilateral acts, for instance the publication of a corporate code in a factory or reference to it in a report, as an integral part of the employment contract. ${ }^{80}$ A possible explanation for considering them legally binding could be the stronger proximity between the company as employer and the employee, but also the fact that once they are considered binding, courts can regulate and control these codes of conduct on the ground of labour law. The most famous example is the case against Wal-Mart in Germany, in which a labour court considered the unilateral code of conduct to be a document constituting rights and obligations for employees and argued that this code of conduct would have to be reconciled to be in compliance with the rules on co-determination and the constitutional rights of employees. ${ }^{81}$ Hence, what can be seen in this case is how a different doctrine, namely the horizontal effect of human rights, served as an important trigger for the law to sidestep the established doctrine that contractual obligations are created bilaterally, which it then used to exercise control over the unilateral regulatory measure. ${ }^{82}$

Moreover, the legally binding character of unilateral declarations is also partly furthered through consumer law with reliance on the legitimate expectations of consumers. In the debate on the legally binding effect of corporate codes of conduct on the consumer market, attention is also paid to the fact that pre-contractual marketing statements are considered in shaping the rights of consumers in

${ }^{78}$ See, with further references to national debates, Vytopil, Contractual Control in the Supply Chain. On Corporate Social Responsibility, Codes of Conduct, Contracts and (Avoiding) Liability, p. 73-76; 89; Rühmkorf, Corporate Social Responsibility, Private Law and Global Supply Chains, p. 95-6.

${ }^{79}$ See (with important variations on how this binding effect is justified and thus how far it can be taken) Bachmann, Private Ordnung, p. 278ff. (based on the intention of the corporation, the foreseeability of liability risk and the intention to provoke reciprocity); Herberg, Globalisierung und private Selbstregulierung. Umweltschutz in multinationalen Unternehmen, p. 114f. (based on the concept of unilateral declarations); C. Glinski, 'Corporate Codes of Conduct: Moral or Legal Obligation?' in D. McBarnet, A. Voiculescu and T. Campbell (eds.), The New Corporate Accountability Corporate Social Responsibility and the Law (Cambridge University Press, Cambridge 2007), 119-47, p. 122ff. (based on the legitimate expectations of consumers); L. Moerel, Binding Corporate Rules: Corporate Self-Regulation of Global Data Transfers (Oxford University Press, Oxford 2012), p. 132ff. (based on the doctrinal category of the unilateral undertaking and regarding binding corporate rules); Beckers, Enforcing CSR Codes, Chapter 7 \& p. 366ff. (based on a combination of intention and the reasonable reliance of market actors).

${ }^{80}$ See, for the U.S., Weber Shandwick Worldwide v Reid et al, District Court, Northern District of Illinois, No 05 C 709 , decided 12 May 2005; Brinkley v Honeywell, United States Court of Appeal for the $9^{\text {th }}$ Circuit, 35 F.3d 570, Guz v Bechtel National Inc., Court of Appeal for the $1^{\text {st }}$ District Division, 8 P.3d 1089, all discussed in K. E. Kenny, 'Code or Conduct: Whether Wal-Mart's Code of Conduct Creates a Contractual Obligation Between Wal-Mart and the Employees of its foreign suppliers' 27 Northwestern Journal of International Law and Business, 453-74, p. 459ff. See, for Germany, the so-called 'betriebliche Übung', BAG NJW 1963, 1996, 1996. See also Bachmann, Private Ordnung, p. $285 f f$. For the Netherlands, cf. also the Batco-case, Ondernemingskamer [Dutch Company and Business Court], 21 June 1979, NJ 1980, 71 , in which the court considered a commitment by the company to the OECD Guidelines to create binding obligations of the company to consult employee representatives before closing down a factory.

${ }^{81}$ ArbG Wuppertal, NZA-RR 2005, 476, LAG Düsseldorf NZA-RR 2006, 81. Cf., in detail for the influence of constitutional rights on codes of conduct for the German context, Klösel, Compliance-Richtlinien. Zum Funktionswandel des Zivilrechts im Gewährleistungsstaat, p. $57 \mathrm{ff}$.

${ }^{82} \mathrm{Cf}$., for the value of the doctrine of horizontal effect in the enforcement and control of transnational private regulation in general, E. Benvenisti and G. Downs, 'National courts and transnational private regulation' in F. Cafaggi (ed.), Enforcement of Transnational Regulation Ensuring Compliance in a Globalized World (Edward Elgar Publishing, Cheltenham 2012), 131-46, p. 137 f. 
a contract. ${ }^{83}$ The Court of Justice of the European Union went as far as to decide that in the specific constellation of prize notifications, unilateral promises that are made towards consumers for marketing purposes can be understood as being of a contractual nature. ${ }^{84}$ This jurisprudence could arguably be used to inform the broader enforcement of unilateral promises towards consumers. ${ }^{85}$

On the other hand, in relation to parties that receive less specific legal protection, unilateral declarations seem to be considered less a source of obligation. This applies to their effect towards other commercial parties ${ }^{86}$ as well as towards the ultimate beneficiaries of the code of conduct - local communities, employees in supplier factories, and those affected by breaches of environmental commitments, ${ }^{87}$ although on the ground of the principle of reasonable reliance of the addressees even this is occasionally suggested. ${ }^{88}$ In this context, it should be noted that recent developments in tort law suggest that the presence of corporate codes might help in establishing tort liability of a company if a breach of a code results in damage ${ }^{89}$ but from the contract law perspective there remains strong reluctance to consider such unilateral corporate codes as creating contractual or quasi-contractual obligations that are enforceable by those affected.

One can thus see that already within contract law doctrine, quite different approaches are taken to dealing with these strategic attempts by companies to use the unilateral declaration as the form for their codes. These can range from a general perception of their non-binding character due to a lack of reciprocity to a differentiation between different interest groups relying on such codes. Their treatment can become even more complex if one broadens the perspective beyond the debate in contract law to other areas of private law that are affected by the use of corporate codes. Without going into much detail here, I would like to mention at least one other area which is affected by the use of codes of conduct. A unilateral commitment to comply with a corporate code could result in liability for unfair trading behaviour if the communication is directed towards consumers and the

${ }^{83}$ See Glinski, 'Corporate Codes of Conduct' p. 124ff; A. Barron, 'Reasonable Expectations, Good Faith and Self-Regulatory Codes' in G. Howells and others (eds.), The Yearbook of Consumer Law 2007 (Ashgate Publishing, Aldershot 2007), 330 .

${ }^{84}$ Case C-96/00 Rudolf Gabriel [2002] ECR I-06367; Case C-27/02 Petra Engler v. Janus Versand GmbH [2005] ECR I00481; Case C-180/06 Renate Ilsinger v. Martin Dreschers, [2009 ]ECR I-3961.

${ }^{85}$ See, for this suggestion, Bachmann, Private Ordnung, p. 298; Beckers, Enforcing CSR Codes, p. $373 \mathrm{f}$.

${ }^{86}$ See, for a sceptical position regarding English law, Rühmkorf, Corporate Social Responsibility, Private Law and Global Supply Chains, p. 95f; regarding the CISG, C. Ramberg, 'Emotional Non-Conformity in the International Sales of Goods, Particularly in Relation to CSR-Policies and Codes of Conduct' in I. Schwenzer and L. Spagnolo (eds.), Boundaries and Intersections 5th Annual MAA Schlechtriem CISG Conference (Eleven International Publishing, The Hague 2014), 71-94, p. $80 \mathrm{ff}$.

${ }^{87}$ This can be taken from the case Doe $v$ Wal-Mart Stores, United States of Appeal for the $9^{\text {th }}$ circuit, 572 F.3d 677, in which the employees of a supplier of Wal-Mart could not establish any substantive claim against Wal-Mart on the basis of their code of conduct.

${ }^{88}$ See, for suggestions to this end, Herberg, Globalisierung und private Selbstregulierung. Umweltschutz in multinationalen Unternehmen, p. 115; Phillips and Lim, 'Their Brothers' Keeper', p. 375ff. Cf. also K. Peterkova Mitkidis, 'Sustainability Clauses in International Supply Chain Contracts: Regulation, Enforceability and Effects of Ethical Requirements' Nordic Journal of Commercial Law, 1-30, p. 16ff.

${ }^{89}$ There are at least two noteworthy rulings in this respect: first, in Doe v. Nestle Inc. the U.S. Court of Appeal for the $9^{\text {th }}$ circuit (No. 10-56739, filed September 4th, 2014) considered corporate reliance on and lobbying for voluntary initiatives to be an element that plays a role in assessing whether liability for human rights violations could be assigned to a company on the basis of knowledge. Second, the Court of Appeal in the Hague, in deciding on a question of jurisdiction, substantively assessed the possibility of a parent company being responsible for environmental damage caused by a foreign subsidiary and concluded that it cannot be excluded beforehand that there is no liability, and even more so if the parent has been actively involved in the operational management and made an effort to prevent environmental damage (see Gerechtshof Den Haag, Oguru v. Shell, 18 December 2015, ECLI:NL:GHDHA:2015:3588, para 2.2.: 'eens temeer indien zij een speerpunt heeft gemaakt van het voorkomen van milieuschade door activiteiten van de concernvennootschappen en tot op zekere hoogte actieve bemoeienis heeft met en sturing geeft aan de bedrijfsvoering van die vennootschappen'). 
company does not comply with its code..$^{90}$ The result of applying this remedy, however, aims not at recognition of codes of conduct as a source for legal obligations, as the rules on contract law would suggest, but rather at a prohibition on companies actually communicating their policies. ${ }^{91}$ The opposite interpretation of corporate codes, which would arguably be more in line with the perception in contract law, namely to perceive corporate codes of conduct as a self-imposed threshold for what is considered fair trading behaviour and thus bind companies to their commitments, is in principle possible under unfair commercial practices law, ${ }^{92}$ but it remains highly contested whether corporate codes of conduct would qualify as such. ${ }^{93}$

What this discussion of unilateral declarations under contract law and unfair commercial practices law has thus shown is that the core strategy of companies to use for their codes a form that is not institutionalised in contract law, namely a unilateral declaration, results in a high degree of uncertainty over whether and what form of regulation through private law is appropriate.

\section{(2) Contractual codes of conduct and the threshold of contract interpretation}

As has been discussed above, corporate codes currently partly indeed take a contractual form through which a company seeks to incorporate its code commitments into its contracts with suppliers. From a contract law perspective, it seems less problematic to consider this as being of a contractually binding character. This applies to expressly incorporated terms as much as to codes of conduct that appear in the general terms and conditions, within framework agreements or as a separate contract. ${ }^{94}$ However, in relation to contractual incorporation of codes of conduct the actual conflict within contract law relates to the question of whether this corporate strategy of how the obligations are laid down in the contract is to be accepted or controlled on the grounds of the principles of good faith and fair dealing.

There is little case law on this question with the exception of one U.S. case, in which the Court of Appeals for the $9^{\text {th }}$ circuit ruled that the rights and obligations deriving from a contractually incorporated code of conduct are to be determined with a view to what the parties have explicitly agreed on. According to this understanding, strategically incorporated codes of conduct become legal obligations solely for the supplier. ${ }^{95}$ The academic debate seems to be quite divided on this issue. Some seem to accept that due to the focus on the actual agreement, contract law reaches its limits in enforcing codes of conduct differently than agreed upon by the parties $;{ }^{96}$ others assume that contract law could more actively engage in an interpretation of these contracts in the light of the expectations

${ }^{90}$ See, for the U.S.: Kasky v Nike 45 P 3d 243 (California Supreme Court); and for Germany: Verbraucherzentrale v Lidl, complaint filed at LG Heilbronn 6 April 2010, case settled on 14 April 2010.

${ }^{91}$ I.e. Consumer organisations may seek injunction orders or, although practically not very likely, consumers may withdraw from contracts made in reliance. See extensively Beckers, Enforcing CSR Codes, p. $208 \mathrm{ff}$.

${ }^{92}$ See Art. 6 (2)(b) Unfair Commercial Practices Directive.

${ }^{93}$ See, on the controversy in Germany, e.g., S. Augenhofer, 'German Report' in B. Kilpatrick, P. Kellezi and P. Kobel (eds.), Antitrust in the Groceries Sector \& Liability Issues in Relation to Corporate Social Responsibility (Springer, Heidelberg / New York 2015), 507-30, p. 510-14; R. Podszun, 'Corporate Social Responsibility-Standards: Rechtstheoretische Aspekte und die Frage, was den "Markenkern" der Rechtswissenschaft ausmacht' in R. Hilty and F. Henning-Bodewig (eds.), Corporate Social Responsibility - Verbindliche Standards des Wettbewerbsrechts? (Springer, Berlin / Heidelberg 2014), 51-79, p. 55; Beckers, Enforcing CSR Codes, p. 202-205; A. Birk, 'Corporate Responsibility, unternehmerische Selbstverpflichtungen und unlauterer Wettbewerb' Gewerblicher Rechtsschutz und Urheberrecht, 196-203, p. 198-201; for the situation in the UK: Rühmkorf, Corporate Social Responsibility, Private Law and Global Supply Chains, p. 133137; for some indications as to the legal situation in the Netherlands: Vytopil, Contractual Control in the Supply Chain. On Corporate Social Responsibility, Codes of Conduct, Contracts and (Avoiding) Liability, p. 168-9.

${ }^{94}$ I have labelled these types of incorporation as 'easy' and 'comparably easy' cases in which codes of conduct become legal obligations: Beckers, Enforcing CSR Codes, p. $47 \mathrm{ff}$. See, for similar observations, Vytopil, Contractual Control in the Supply Chain. On Corporate Social Responsibility, Codes of Conduct, Contracts and (Avoiding) Liability, p. 123, 129, 136; Peterkova Mitkidis, 'Sustainability Clauses'13- 15.

${ }^{95}$ Doe v Wal-Mart Stores, United States of Appeal for the $9^{\text {th }}$ circuit, 572 F.3d 677.

${ }^{96}$ Vytopil, Contractual Control in the Supply Chain. On Corporate Social Responsibility, Codes of Conduct, Contracts and (Avoiding) Liability, p. 277f. (with, however, some cautious optimism for their possible enforcement under U.S. (Californian) law.) 
of the parties also expressed in the unilateral corporate declarations that ultimately require the code of conduct and the related commitments of that company to be incorporated in the contract. ${ }^{97}$ One may additionally also consider the application of the rules on unfair contract terms in relation to such contracts to prevent a unilateral imposition of a code of conduct on the other contracting party. ${ }^{98}$ Each of these positions can be based on a valid approach to contract interpretation in contract law. Those arguing for the acceptance of the corporate strategy of imposing limits can rely on contract enforcement according to the objective terms, which reflect the presumed subjective intentions of the parties; those arguing for a stronger consideration of rights of suppliers can base their argument on the principle of protecting the reasonable expectations of the addressee in the publicly available code of conduct on which the contractual clause is based; and finally those arguing for a control on the use of contracts by large companies may be justified on the basis of the contract law principles of fair dealing and good faith. Certainly, a decision for one position or another may be influenced by the national specifics of contract interpretation, ${ }^{99}$ but eventually it remains a decision that leads to a conflict between different principles underlying the creation of obligations in contract law: is it the intention of the parties as expressed in the contract, reliance on the code of conduct as a regulatory tool, or the need to interpret the contractual obligations in the light of fair dealing and good faith in which the code of conduct could play a role?

\section{b) The purpose of codes under contract law}

Next to the difficulties in relation to the form used by companies, from the perspective of contract law the substance of codes also does not fit into established classifications. The following analysis will focus on two characteristics, namely the type of the obligation created through a code of conduct from the perspective of contract law and the threshold that the code of conduct contains, i.e. the substantive standard that companies use as benchmarks for their codes, and the procedural inclusion of regulated parties in the drafting and enforcement process.

\section{(1) The type of obligation under contract law: exchange $v$. regulation}

What, if any, from the perspective of contract law, is the actual type of obligation that companies create when they commit themselves to comply with a corporate code of conduct? Empirical studies suggest a classification as an obligation to undertake a specific process rather than to achieve a certain result. ${ }^{100}$ In the language of obligations under general contract law, this classification is akin to an obligation to perform a service as opposed to a result obligation, as is common in sales or craft contracts. As such, this does not raise difficulties, as contract law could accordingly treat and enforce corporate code obligations as services and rely, if necessary, on the dispositive rules applicable to this type of contract. Nonetheless, for contractually incorporated codes of conduct or those where unilateral declarations can be read into the contract, the basis often remains a sales contract. From the perspective of contract law, this renders the specific process obligation in the section dealing with code compliance somewhat at odds with the overall contractual architecture. Provisions requiring compliance with corporate codes would qualify better as service obligations, although they are incorporated within sales contracts.

\footnotetext{
97 Most prominently, Phillips and Lim, 'Their Brothers' Keeper'., p. $371 \mathrm{ff}$.

${ }^{98}$ See (although with scepticism under current contract law doctrine) Rühmkorf, Corporate Social Responsibility, Private Law and Global Supply Chains, p. 93-4. Effectively, applying the rules on unfair contract terms would require arguing for an application of consumer protection rules to the business-to-business context. See, for suggestions in this direction, J. Klijnsma (2014). The CESL and its unfair terms protection for SMEs. In M.B.M. Loos \& I. Samoy (Eds.), The position of small and medium-sized enterprises in European contract law (Ius commune: European and comparative law series, 121) (pp. 73-81). Cambridge: Intersentia.

${ }^{99}$ On this, see the extensive analysis by N. Kornet, Contract Interpretation and Gap Filling: Comparative and Theoretical Perspectives (Intersentia, Antwerp 2006).

100 Cafaggi, 'The Regulatory Functions', p. 1596f.; P. Verbruggen, 'Regulatory Governance by Contract: the Rise of Regulatory Standards in Commercial Contracts' 35 Recht der Werkelijkheid, 79-100, p. 94-5.
} 
In order to make sense of this term in the overall contractual architecture as a sale, contract law scholars have put much effort into relating the obligation to comply with a code of conduct to sales law obligations. To this end, widening the definition of the product quality to also cover ethical manufacturing practices has been specifically discussed. ${ }^{101}$ This might suggest that there is no real conflict from the contract law perspective, as the commitments taken on in corporate codes of conduct can eventually be reconciled with the general rules on sales. Arguably, however, this attempt to reconcile the commitments in codes of conduct with the rights and duties in sales contracts results in theoretical and practical difficulties. The lack of fit can be most prominently observed when investigating the legal consequences and the remedies that an indirect regulation of codes of conduct via sales law and product regulation would result in. A sales law remedy does not seem to fit with the obligations taken on by a company in a code of conduct: specific performance would not be suitable; an award for damages would require significantly broadening the understanding of what damages can be claimed (damages for failure to regulate or to compensate third party losses); and avoidance and termination, despite remaining suitable remedies, are questionable in terms of their effect on furthering improvements in the socially responsible behaviour on the part of contracting partners. ${ }^{102}$

One possible explanation of the reluctance to apply rules other than sales contract rules to process-oriented code of conduct obligations could be the fact that in traditional contract laws the focus has mostly been on sales contracts with a wide ignorance of service contracts. ${ }^{103}$ In addition, from the contract law perspective there seems to be a difficulty in classifying specific obligations within a contract that deviate from the general purpose of the same contract. It is revealing that corporate codes in contracts are described by scholars as "not the stuff of contract breach"104 and as accommodating a logic different to that typical in domestic contract laws. ${ }^{105}$ To be more concrete, if a corporate code is included in a sales contract, non-compliance with that code does not follow the logic of the contract in which it is included: curing the defect in the sales contract is related to solving the problem of a default in delivery, while the goal of curing non-compliance with a code of conduct is to detect the reason in order to avoid reoccurrence of the violation. ${ }^{106}$ Against this background, from the perspective of contract law, determination of a frame of reference (or dispositive contract rules and remedies) that is applicable to corporate code provisions is an open question: whether to relate it to the exchange logic and consider the rules on sales contracts applicable or to relate it to the logic of regulation and develop self-standing rules for the determination of duties and remedies.

101 See, regarding different national sales laws, e.g., C. Glinski and P. Rott, 'Umweltfreundliches und ethisches Konsumverhalten im harmonisierten Kaufrecht' [Hard Copy Folder] Europäische Zeitschrift für Wirtschaftsrecht, 649-54; O. Dilling, 'Die Produktionsbedingung als Produkteigenschaft - Ein Fallbeispiel für die Haftung bei Werbung mit ethischen Produktionsstandards nach der Schuldrechtsreform' in G. Winter (ed.), Die Umweltverantwortung multinationaler Unternehmen Selbststeuerung und Recht bei Auslandsinvestitionen (Baden-Baden, Nomos 2005), 283313; Kocher, 'Codes of Conduct and Framework Agreements on Social Minimum Standards - Private Regulation?', p. 78f.; A. G. Castermans, De burger in het burgerlijk recht of De eigenschappen van perensap (Boom Uitgevers, Den Haag 2009). Regarding the CISG affirmatively, see I. Schwenzer and B. Leisinger, 'Ethical Values and International Sales Contracts' in R. Cranston, J. Ramberg and J. Ziegel (eds.), Commercial Law Challenges in the 21st century: Jan Hellner in memorium (Stockholm Centre for Commercial Law Juridiska Institutionen, Stockholm 2007), 249-75, p. 265f.; and, critically, Ramberg, 'Emotional Non-Conformity in the International Sales of Goods, Particularly in Relation to CSR-Policies and Codes of Conduct', p. $82 \mathrm{ff}$.

102 See, on the difficulties, extensively, Beckers, Enforcing CSR Codes, p. $121 \mathrm{ff} ., 147 \mathrm{f}$.

${ }^{103}$ See, for this observation, H. Micklitz, 'The Internal vs. the External Dimension of European Private Law - A Conceptual Design and A Research Agenda' in M. Cremona and H. Micklitz (eds.), Private Law in the External Relations of the EU (Oxford University Press, Oxford 2016), 9-31, p. 12.

${ }^{104}$ Backer, 'Multinational Corporations as Objects and Sources', p. 518.

${ }^{105}$ Cafaggi, 'The Regulatory Functions', p. 1612f.

${ }^{106}$ Ibid., p. 1616. 


\section{(2) The substantive contract obligation: private agreement $v$. political substance}

Generally speaking, corporate codes are a tool through which companies commit themselves to adhere to standards that concern matters of public interest. ${ }^{107}$ They commonly contain commitments related to human rights protection, fundamental labour standards, the prevention of corruption and environmental protection. Hence, these forms of codes of conduct have a strong public interest dimension. Recalling what has been described above, one can identify several layers in this respect: codes of conduct appear to contain references to established national public law frameworks and to international conventions, but they also contain autonomous standards through which companies react to social pressures.

The key to understanding the difficulty with contract law doctrine in treating this novel content of commitments is related to the public/private divide and the content of this new dimension of how public interests, as laid down in international soft law, treaties or national (labour or environmental) law, become relevant in private law. So far, public interests in private law have been primarily discussed as being linked to the sphere of state or public policy and emphatically not as elements that are incorporated into a private contract or a unilateral declaration. This is exactly the aspect in which corporate codes are novel: they have a strong public interest dimension, but this appears without a direct involvement of the state as the regulator. In contract law terms, public interests appear not in the form of mandatory rules, as has been the case for consumer protection laws or labour laws, but they appear as a choice by companies to make these policies subject to their global business operations. How can contract law deal with such autonomous choices? A likely answer from traditional contract law would be to interpret such commitments in the light of the intention of the parties, but this seems questionable against the background of precisely the public dimension of the issues agreed upon. One could also suggest as a frame of reference for such commitments not the traditional logic of private contracting but the public framework that they refer to. ${ }^{108}$ As a result, international political frameworks could be used to determine the content of vague provisions in corporate codes. One could even go further by arguing that this new corporate role exhibited in codes of conduct requires a new form of materialist private law, in which contractual obligations are generally controlled to the extent to which they fulfil their public role and which considers private contracts void if this is not the case. ${ }^{109}$

To be more concrete, the problem can be exemplified by considering the incorporation of labour standards. How do corporate codes, if understood as private regulatory activities, relate to regulation by the state through mandatory laws? Is the commitment to protect fundamental labour standards to be interpreted in accordance with the text of the corporate code in the light of the national law, or does it require interpretation in the light of the ILO core labour rights (provided the protection is higher than under national law)? One might be tempted to say that there ultimately remains a hierarchy in which mandatory rules are superior to commitments in corporate codes, a position also expressed by the German Labour court when ruling on Wal-Mart's code of conduct. ${ }^{110}$ However, when the perspective is widened and focused on global corporate activities, this accepted hierarchy does not seem so clear-cut. If corporate codes are directed towards improving the situation for workers in national contexts where labour law is restrictive or absent, it seems to be less accepted that this perceived hierarchy is still valid. In fact, in their relations with countries with weak labour standards, companies are confronted with the conflicting expectation of not breaching national laws and at the

${ }^{107}$ Cf., in this respect especially, K. Webb, 'Understanding the Voluntary Codes Phenomenon' in K. Webb (ed.), Voluntary Codes: Private Governance, the Public Interest and Innovation (Charleton University, School of Public Policy and Adminstration, Ottawa 2004), 3-32, p. 13-15.

108 See, with a view to the specific case of framework agreements, S. Coleman, 'Enforcing International Framework Agreements in U.S. Courts: A Contract Analysis' 41 Columbia Human Rights Review, 601-34, p. 623f., 632.

${ }^{109}$ A strong case for such an approach is made by L. K. L. Tjon Soei Len, The effects of contracts beyond frontiers: A capabilities perspective on externalities and contract law in Europe ( $\mathrm{PhD}$ Dissertation, Universiteit van Amsterdam, Amsterdam 2013). Also cf., for the classification of this dimension as a new form of welfarist contract law, T. Wilhelmsson, 'Varieties of Welfarism in European Contract Law' 10 European Law Journal, 712-33, p. 723.

${ }^{110}$ See above n. 81 . 
same time not contributing to a race to the bottom, taking into account the higher standards as expressed in their codes or a legal obligation in their home country. ${ }^{111}$ In this context, there is competition between (nationally legitimised) public law and the higher standard in the corporate code, or in the code interpreted in the light of the ILO core labour standards. Is it, against this background, possible to consider codes of conduct to be subordinated to state law? Do they receive equal recognition on the ground of a public interest in achieving effective global corporate self-regulation in the public interest that is similarly as important as regulation by the state? And what happens in the most difficult case where the code actually breaches national laws or does not comply with the ILO core labour standards?

\section{(3) Participation and accountability in codes: privity $v$. public governance}

This discussion on determining the content of corporate codes in contract law is arguably closely related to a third aspect of corporate codes in which they conflict with contract law. The reason is the fact that the incorporation of public laws raises questions of procedural legitimacy that contract law doctrine cannot account for. As one observer puts it, 'Competition between public and private regimes at transnational level occurs when private actors raise the standards defined by the public actor, thereby decreasing the legitimacy of public regulation and taking leadership without being subject to the procedural requirements applied to international public law regimes. ${ }^{112}$ The inherent suspicion of fully recognising corporate codes of conduct as regulation that furthers public interests is not only related to the substance of the obligations included in codes and their possible interpretation in the light of the referenced public sources; it is a matter of their governance structure and therefore their procedural legitimacy basis.

As a starting point, it may be useful to emphasise that corporate codes remain private and firm-dominated instruments. In this regard, they have to be distinguished from other forms of code of conduct that are investigated in this section, namely those developed by an organization to govern the behaviour of its members and the multilateral agreements between individual firms within an industry or a sector. The influential framework of global governance mechanisms developed by Abbott and Snidal underlines this. In their typology of the governance triangle, codes of conduct of multinational corporations are classified in the firm-centred 'zone'. ${ }^{113}$ On the micro level, this understanding can be confirmed by empirical sociological research that has shed light on how corporate codes are adopted. In companies it is the senior management and the board of directors that make the ultimate decision on how the code of conduct should look. ${ }^{114}$ In principle, one can relate corporate codes to a specific form of corporate governance in that they appear in the form of firm guidelines governing the internal organisation, ${ }^{115}$ or as part of contract governance once they are incorporated into global distribution networks to govern contractual relations. ${ }^{116}$ According to this perception, companies use a unilateral declaration as a governance instrument for their global corporate operations and bilateral contracts for

\footnotetext{
111 This is most apparent in relation to labour rights and the prohibition of discrimination and the freedom of association. Cf. McBarnet and Kurkchiyan, 'CSR through Contractual Control?', p. 70ff.

${ }^{112}$ Cafaggi, 'New Foundations of Transnational Private Regulation', p. 45.

${ }^{113}$ K. Abbott and D. Snidal, 'Strengthening International Regulation Through Transnational New Governance: Overcoming the Orchestration Deficit' [GT el] 42 Vanderbilt Journal of Transnational Law, 501-71, p. 512-517.

${ }^{114}$ Herberg, Globalisierung und private Selbstregulierung. Umweltschutz in multinationalen Unternehmen, p. $77 \mathrm{f}$.

${ }^{115}$ On corporate codes of conduct as corporate governance instruments in the practice of companies, see Bondy, Matten and Moon, 'The Adoption of Voluntary Codes in MNCs: A Three-Country Comparative Study'. On the conceptual link between corporate governance and CSR (with the consequence of CSR codes of conduct becoming effectively corporate governance instruments, see for further references J. Eijsbouts, Corporate responsibility, beyond voluntarism. Regulatory Options to reinforce the license to operate (Inaugural Lecture, Maastricht University, Maastricht 2011), p. 42ff.

${ }^{116}$ For the understanding of corporate codes as an instrumental complement to contract governance, cf. Micklitz, 'The Internal vs. the External Dimension of European Private Law - A Conceptual Design and A Research Agenda', p. 25. Cf., on the concept of contract governance in general, S. Grundmann, F. Möslein and K. Riesenhuber, 'Contract Governance: Dimensions in Law and Interdisciplinary Research' in S. Grundmann, F. Möslein and K. Riesenhuber (eds.), Contract Governance: Dimensions in Law and Interdisciplinary Research (Cambridge University Press, Cambridge 2015), 3-58.
} 
other companies linked to them through a market relationship, and all of this has the purpose of implementing the previously set standards in the light of social demands. However, the governance structure and governance effects go beyond this internal corporate and external contractual dimension. First, in the drafting process, a corporate code of conduct is not made without interaction with the external environment. In response to increasing social pressure on companies to improve their codes, one can also observe a trend of increasing cooperation between corporations and non-governmental organisations. ${ }^{117}$ From the perspective of companies, this collaboration is relied on in order to enhance the social legitimacy of the individual company code, to become aware of social forces and trends, to establish networks, and to make use of specific expertise that companies may not have. ${ }^{118}$ At the same time, it has to be noted that this external input, from NGO collaboration or reconciliation of codes with state law, does not lead to a form of participatory governance in which companies are at the receiving end; on the contrary, companies actively and unilaterally shape this input according to their own interests and objectives. ${ }^{119}$

Second, the governance effect of corporate codes expands beyond the corporate entity and the supply chain towards the 'outside' global public sphere, as they effectively regulate individuals (employees, neighbours), communities (respect for the rights of indigenous communities) and even the public good (the environment). Hence, corporate codes have distributional effects ${ }^{120}$ and are criticised in relation to their legitimacy. ${ }^{121}$ It is this lack of public legitimacy and their firm-centred character that are a reason for the reluctance to accept standards developed autonomously by companies on a similar footing to mandatory rules in contract law.

Arguably, these procedural requirements regarding the involvement of regulated actors are precisely the question underlying the debate on whether corporate codes should be interpreted under contract law as creating third-party rights or whether the doctrine of the privity of contracts prevents this. What contract law is confronted with is the difficult undertaking of determining whether and to what extent the requirements for public governance, such as transparency, accountability and the participation of those affected, would also need to be observed in the process of negotiating and enforcing codes of conduct if they are treated as contracts. In other words, "The development of such mechanisms would require significant new forms of legal innovation, and we should therefore begin thinking more imaginatively about how we might appropriately adapt instruments of tort law, contract law and liability law to empower stakeholders to defend their own democratic entitlements in situations where other powerful actors fail to respond appropriately to their interests and expressed preferences." $" 122$

To consider such requirements within the context of contract law, in particular the participation of and accountability towards affected regulated parties and requests for transparency, is immensely difficult as it contradicts the principles of party autonomy and the privity of contractual obligations in contract law. It would also entail a quite far-reaching liability risk for the corporate

117 See, for references to empirical studies and a typology of the different forms, M. Yaziji and J. Doh, NGOs and Corporations. Conflict and Collaboration (Business, Value Creation, and Society, Cambridge University Press, Cambridge 2009), p. 123-29; O. Dilling, 'From Compliance to Rulemaking: How Global Corporate Norms Emerge from Interplay with States and Stakeholders' 13 German Law Journal, 381-418, p. 405ff. Cf. also H. Micklitz, 'Organisation und öffentliche Güter' in S. Grundmann, H. Micklitz and M. Renner (eds.), Privatrechtstheorie (Mohr Siebeck, Tübingen 2015), 1654-72, p. 1667.

118 Yaziji and Doh, NGOs and Corporations. Conflict and Collaboration, p. 127-129.

119 Dilling, 'From Compliance to Rulemaking: How Global Corporate Norms Emerge from Interplay with States and Stakeholders', p. 408.

${ }^{120}$ See, for this observation, F. Cafaggi and K. Pistor, 'Regulatory capabilities: A normative framework for assessing the distributional effects of regulation' 9 Regulation \& Governance, 95-107, p. 96.

${ }^{121}$ See, e.g., R. Wai, 'Private v Private: Transnational Private Law and Contestation in Global Economic Governance' in H. Muir Watt and D. P. Fernández Arroyo (eds.), Private International Law and Global Governance (Cambridge University Press, Cambridge 2014), 34-54, p. 41f.

${ }^{122}$ T. MacDonald and K. MacDonald, 'Non-Electoral Accountability in Global Politics: Strenghtening Democratic Control within the Global Garment Industry' 17 European Journal of International Law, 89-119, p. 117. 
entity. One could discuss initiating the aforementioned 'significant new forms of legal innovation' by broadening existing rules that deal with third-party effects of contracts. This would mean considering corporate codes as creating third-party rights in contracts ${ }^{123}$ or applying, for instance, the doctrine of transferred losses to allow contracting parties to claim losses by third parties ${ }^{124}$ to ensure accountability. One might also consider interpreting the restrictions in national contract laws on concluding contracts to the detriment of third parties without their consent in a wide sense as being essentially an obligation of code drafters to include those affected by their regulation in the regulation process. However, given the broad scope of governance through corporate codes (employees and communities in other countries, the global public's interest in environmental protection), such a considerable broadening without an option for companies to exclude such far-reaching liability is naturally highly disputed ${ }^{125}$ and it is argued that even if it were established, companies would immediately seek to reduce their liability risk by including disclaimers. ${ }^{126}$

A different option would be to rely on existing contract law, where a degree of participation and accountability towards third parties is already provided for, in particular the rules on employee participation in corporate governance. In a very concrete way, this would suggest being able to hold companies accountable for non-compliance and considering those participating in the drafting of a code, namely employee representatives (or even consumers), as agents of those that are eventually regulated. However, given the rather narrow scope of these rules, which apply only insofar as direct employees of a company are concerned, they may not provide sufficient grounds to legitimise the public governance dimension of codes of conduct that deal with other areas. In fact, one may even go so far as to argue that reliance on the existing rules on the participation of labour for the broader purpose of other aspects of CSR (human rights, environmental protection) could be counterproductive for the realisation of these very objectives. In drafting codes of conduct, the perspectives of human rights and labour issues may contradict each other. ${ }^{127}$ A similar view may be held with respect to the accountability of companies for code compliance towards consumers that consumer sales law can provide for and its conflict with the labour dimension and the environmental dimension in codes of conduct. ${ }^{128}$

Consequently, the inherent conflict in contract law relates to the question of the extent to which contract rules that are envisaged to cover the negotiation and enforcement of private contracts between two contractors can be used for constellations where companies effectively agree to regulate the public sphere through codes of conduct. Or concretely, whether the limited and exceptionally applied rules on the third-party effects of contracts under the rules of contract formation and enforcement can accommodate the participation and accountability of regulated collectives.

${ }^{123}$ For a discussion of third party rights in CSR codes of conduct and related suggestions on their expansion under English law, see Rühmkorf, Corporate Social Responsibility, Private Law and Global Supply Chains, p. 211. Cf. also the detailed analysis by Vytopil on the possibility of interpreting contractually incorporated codes of conduct as creating third party rights: Vytopil, Contractual Control in the Supply Chain. On Corporate Social Responsibility, Codes of Conduct, Contracts and (Avoiding) Liability, p. 242ff., 250ff., 256ff.

${ }^{124} \mathrm{See}$, for a proposal in this direction, but regarding the third-party effects of the financial crisis, S. Grundmann and M. Renner, 'Vertrag und Dritter - Zwischen Privatrecht und Regulierung' Juristenzeitung, 379-89. For a consideration of its application in the context of corporate codes of conduct, see Beckers, Enforcing CSR Codes, p. 164f.

${ }^{125}$ For a sceptical position on such an extension, see specifically Bachmann, Private Ordnung, p. 297.

${ }^{126}$ See, e.g., C. Estlund, 'Enforcement of transnational labor regulation: a new frontier in the anti-sweatshop movement?' in F. Cafaggi (ed.), Enforcement of Transnational Regulation Ensuring Compliance in a Global World (Edward Elgar Publishing, Cheltenham 2012), 237-62, p. 255.

${ }^{127}$ See, pointedly, R. Braun and J. Gearhart, 'Who Should Code Your Conduct? Trade Union and NGO Differences in the Fight for Workers' Rights' 14 Development in Practice, 183-96, p. 187-189 who describe the conflict between human rights and trade union tactics along three dimensions: teleological (ideals vs. interests), structural (free agency vs. accountability towards members) and operational (transcending politics vs. involvement in politics).

${ }^{128}$ See, on the conflict between consumer and labour interests, A. Sobczak, 'Are Codes of Conduct in Global Supply Chains Really Voluntary? From Soft Law Regulation of Labour Relations to Consumer Law' 16 Business Ethics Quarterly, 16784 , p. $177 \mathrm{ff}$., and on the conflict between consumers and the environment, T. Wilhelmsson, 'Consumer Law and the Environment: From Consumer to Citizen' 21 Journal of Consumer Policy, 45-70, p. 49. 


\section{The inevitable normative question: towards contract law as regulating corporate codes of conduct?}

The conflicts and uncertainty within contract law on how to deal with the phenomenon of corporate codes of conduct and their strategic and selective use of contracts for regulatory purposes inevitably raise normative questions. What, if any, is the role that contract law should play in relation to codes of conduct? Should these new forms of corporate private regulation be subject to contract law and for what purpose? Given this apparent need to discuss such normative questions, I will proffer a normative argument in relation to corporate codes of conduct in favour of a stronger judicial enforcement of these codes and contextualise it.

\section{The argument: Towards enforcement of corporate codes of conduct}

By means of an approach theoretically grounded in sociological jurisprudence, and thus the normative need of the law to react to the potential and risks of new social phenomena, ${ }^{129}$ I have developed elsewhere the argument that private law, including contract law, should take a more active role in enforcing and thereby regulating these types of code of conduct. ${ }^{130}$ The core normative argument is the necessary role of the legal system, which includes contract law, to put greater trust in the social institution of private regulation through codes of conduct, and thus in the regulatory role of corporations. Within this architecture, the specific purpose of contract law is envisaged as enforcing these codes and complementing a company's duties undertaken through a code of conduct in its role as a private regulator. To this end, contract law would need to be more regulatory, but regulatory in a novel sense. It would have to become 'a law for private regulators'. More concretely, contract law would need to enforce corporate codes as legal obligations on the part of the corporate entity through contextual contract interpretation and the acceptance of a unilateral declaration as a source of a legal obligation. It would further need to be responsive towards the regulatory role that is pursued through codes of conduct by means of interpreting such legal obligations not as being directed towards conducting an exchange between two parties but as obligations to act as private regulators towards those that are regulated. For this purpose, the duties of private parties and the remedies for breach of contract would need to be, procedurally and substantively, informed by public law frameworks, and third-party rights would require to be more extensively used for these types of contract. Methodologically, I see the core actors to initiate such a transformation of contract law as being primarily domestic courts in deciding cases. ${ }^{131}$ Their role becomes arguably more important once enforcement rights do not remain restricted to the companies involved, but expand to cover the rights of the beneficiaries of codes, of the regulated actors affected.

\section{The context: private regulation, contract law and public regulation}

Such a strong normative argument naturally faces several types of criticism, in particular the concern that using contract law to enforce private regulation in the public interest would destroy the integrity of several, if not all, of the areas involved: private regulation, contract law and public law.

\footnotetext{
${ }^{129}$ See, e.g., on this criterion, G. Teubner, 'Coincidentia oppositorium: Hybrid Networks beyond Contract and Organization' in M. Amstutz and G. Teubner (eds.), Networks: Legal Issues of Multilateral Cooperation (Hart Publishing, Oxford 2006), 3-30, p. 10.

${ }^{130}$ See, Beckers, Enforcing CSR Codes, Chapters $7 \&$ 8. For the comparative dimension of this enforcement, see A. Beckers, 'Doe v Wal-Mart Stores: Zur Praxis einer rechtsvergleichenden soziologischen Jurisprudenz' in B. Lomfeld (ed.), Die Fälle der Gesellschaft: Praxis der soziologischen Jurisprudenz (Mohr Siebeck, Tübingen 2016), and, for its application in public procurement law, A. Beckers, 'Using contracts to further sustainability? A contract law perspective on sustainable public procurement' in B. Sjåfjell and A. Wiesbrock (eds.), Sustainable public procurement under EU law New perspectives on the state as stakeholder (Cambridge University Press, Cambridge 2015), 264-92.

${ }^{131}$ See, generally, on the role of national courts in relation to the regulation of global administrators (but not considering corporate codes of conduct), B. Kingsbury, 'Weighing global regulatory rules and decisions in national courts' 09 Acta Juridica, 90-119. It is clear that this strong focus on courts raises more fundamental questions as to the legitimacy of courts in initiating such a development and their relation to the roles of the legislator and the administration, the justification for which would, however, need to be reserved for another occasion.
} 
First of all, corporate codes are private and global regulatory processes for companies that are deliberately detached from the state and have their strengths in their character as social ordering, which legalization would jeopardise. ${ }^{132}$ This argument is related to socio-legal scholarship in general that argues that it is social ordering and not legal enforcement that steers the behaviour of commercial actors, including companies, at a global level and that legal enforcement even destroys such social dynamics. This negative tendency of over-regulation could, however, be met if one integrates the argument to enforce corporate codes of conduct through contract law within a larger context of different regulatory mechanisms. In this respect, the use of contract law and contract law enforcement is not the only mechanism to ensure compliance, but rather an element that is used when social ordering proves to be insufficient. Approaching it through the lens of the well-known enforcement pyramid developed by Ayres and Braithwaite, ${ }^{133}$ it could be understood as being located at the intermediate level that is used when relational enforcement fails but a case of corporate misconduct sufficiently severe for state intervention in the form of administrative or even criminal penalties is not reached. Enforcement through courts could be made dependent on the condition that an internal mechanism to restore compliance and settlement had failed, for instance an internal third-party complaint mechanism that it set up at the company level; or it might be possible to distinguish the severity of the damage caused through a breach of the code and allow legal enforcement only in cases of serious breaches. ${ }^{134}$ Conceptualised in this way, reliance on contract law to enforce corporate codes of conduct would have two purposes. First, it would be a mechanism that can be invoked when social ordering processes fail, i.e. when disputes cannot be solved informally, when relational sanctions do not lead to compliance, or when a certain threshold has been reached. It would thus function as a true private law mechanism that relies on the willingness of private actors to initiate such a claim. Second, it would also be valuable as a legal framework that on the basis of being a mere possibility could have an impact on the effectiveness of social ordering. ${ }^{135}$ Hence, the existence of formal sanctions for noncompliance could strengthen the way in which relational sanctions and informal corrective measures are handled between the parties. ${ }^{136}$ This function of contract law to structure the social space arguably seems to be of crucial importance in the current state of codes of conduct. First, these codes represent attempts by companies to show the public a serious and effective commitment to self-regulation, but one needs to add in a potential high degree of distrust towards companies with them risking not being taken seriously. ${ }^{137}$ In this situation, contract law could then help enhance social trust in this form of private regulation by enforcing it. Second, as is supported by empirical studies on private compliance programmes, the effectiveness of corporate codes as social ordering seems to remain limited if they

${ }^{132}$ For this criticism on the enforcement of codes of conduct, see L. C. Backer, 'A Lex Mercatoria for Corporate Social Responsibility Codes without the State? A Critique of Legalization within the State under the Premises of Globalization ' 24 Indiana Journal of Global Legal Studies, forthcoming; and M. Kawakami, 'Pitfalls of Over-legalization: When the Law Crowds Out and Spills Over' ibid

${ }^{133}$ I. Ayres and J. Braithwaite, Responsive Regulation. Transcending the Deregulation Debate (Oxford Socio-Legal Studies, Oxford University Press, Oxford 1992)

134 On such a distinction between serious and non-serious infringements as a threshold for enforcement (regarding specifically the administrative enforcement of EU private law), see H. Micklitz, 'Administrative Enforcement of European Private Law' in R. Brownsword and others (eds.), The Foundations of European Private Law (Hart Publishing, Oxford 2011), 563-91.

${ }^{135}$ For this argument, one is back with the assumptions of legal realism, in particular their emphasis on the law as providing the background parameters for the effectiveness of social ordering. See the works of Hale and Hohfeld, Wai, 'Private v Private: Transnational Private Law and Contestation in Global Economic Governance', p. 46f.

${ }^{136}$ For this argument with further references to sociological studies, see Kagan, Gunningham and Thortnon, Peterkova Mitkidis, 'Sustainability Clauses', p. 21f.

${ }^{137}$ Pointedly, see Herberg, Globalisierung und private Selbstregulierung. Umweltschutz in multinationalen Unternehmen, p. 75: 'Die Verhaltenskodizes der Konzerne sind daher nicht einfach ein Mittel der Imagepflege wie jedes andere, sie sind ein spezielles Mittel der Werbung um öffentliches Vertrauen, und zwar, so sei hinzugefügt, unter den Bedingungen erheblicher Legitimations- und Vertrauensprobleme.' 
are not (as is currently often the case) accompanied by complementary legal regulation. ${ }^{138}$ In this respect, contract law could be one of the elements in such a regulatory framework, which, rather than undermining it, could in fact strengthen this form of private regulation.

Second, a stronger interaction between contract law and corporate codes with the objective of regulating companies as private regulators must remain controversial from the perspective of contract law scholars who fear that a transformation could jeopardise the integrity of contract law doctrine. This criticism has been expressed specifically with a view to the enforcement of unilateral declarations, ${ }^{139}$ but it can be expanded to other aspects as well. Suggestions to extend the scope of third-party rights and to restrict the autonomy of corporations to exclude legal accountability for their regulatory activities through disclaimers are apparent examples. These examples effectively relate to a broader crucial point about how far legal concepts can be reconciled with developments in practice without destroying the very character of contract law as a system. Preserving the integrity of legal doctrine is not a value on its own, but it is important to safeguard the social function that the legal system fulfils, namely to stabilise social expectations by applying general pre-developed and predictable norms to actual cases and maintaining the unity in the system. ${ }^{140}$ However, it is clear that preserving its internal unity and coherence is not the only requirement facing the legal system. There is also a need of the law to remain responsive towards its social environment, to social inequalities, risks and political struggles, and on numerous occasions the courts have shown that they are prepared to react to such external changes. ${ }^{141}$ In terms of developing contract law and corporate codes, this implies that the underlying question is primarily a normative question about achieving a balance between social responsiveness and internal integrity, and, moreover, about the time span in which such a change of contract law doctrine should take place. If one considers the quite far-reaching paradigmatic changes within contract law itself in the past from formal to materialist conceptions of contract, the idea that a regulatory conception of contracts and a related contract law could be initiated is not too far-fetched. Provided the development of private law for corporate codes is perceived as a long-term evolution and a careful change of existing doctrinal structures rather than a short-term rupture, and that it is developed on the basis of the existing case law, and, moreover, is accompanied by a continuing emphasis on the role of corporations as regulators, the risk to the doctrinal integrity of contract law might not be too severe.

Finally, a core criticism that can be raised specifically on the part of public law regards reliance on codes of conduct and, for that purpose, contract law to further public interests rather than strengthen the role of national and international public regulation. Theoretically, this furthering of public values by market actors with only nominal true political intervention jeopardises the public sphere where public interests were traditionally furthered by the elected legislator rather than by private actors. ${ }^{142}$ This criticism certainly raises deep questions related to legitimacy and the capability of private actors to establish effective private regulation. They cannot be answered here, but I would like to discuss two elements that might at least moderate this criticism. One of these is to again emphasise that the use of contract law to enhance trust in corporate codes is not meant to be neglecting the role of politics, but rather as an instrument within an overarching framework that requires different

\footnotetext{
${ }^{138}$ In this regard, see the study on labour standards in supply chains by R. Locke, The Promise and Limits of Private Power: promoting labour standards in a global economy (Cambridge University Press, Cambridge 2013), who concludes (Chapter 7) that private compliance programmes require complementary legal regulation in order to be effective.

${ }^{139}$ See, prominently, J. Smits, 'Enforcing Corporate Social Responsibility Codes Under Private Law, Or: On the Disciplining Power of Legal Doctrine ' 24 Indiana Journal of Global Legal Studies, forthcoming.

${ }^{140}$ N. Luhmann, Law as a Social System (Oxford Socio-Legal Studies, Oxford University Press, Oxford 2004), p. 159.

141 J. Ellis, 'Sustainable Development and Fragmentation in International Society' in D. French (ed.), Global Justice and Sustainable Development (Martinus Nijhoff, Leiden 2010), 57-74, p. 61f., mentions as an example Rylands v Fletcher (1866), LR 1 Ex 265. In the socio-legal literature, another prominently mentioned example is Brown $v$ Board of Education 347 U.S. 483.

${ }^{142}$ See, for instance, E. Christodoulidis, 'On the politics of Societal Constitutionalism' 20 Indiana Journal of Global Legal Studies, 629-63
} 
complementary measures. ${ }^{143}$ Another more complex vision relates to the insistence that any use of contract law in relation to corporate codes can never be envisaged as being informed only by the economic imperative, but always needs to consider the political claim to effectively regulate selfregulatory measures in the light of public concerns. The need to use contract law in relation to corporate codes rests on the assumption that there is a need for the law to emphatically not merely accept the claims of individual companies for authorship and legitimacy, but to constantly take into account the requirement of 'publicness. ${ }^{144}$ In this sense, the use of contract law to enforce corporate codes is understood as needing to remain in proximity to the political discourse and as being informed by public law requirements.

\section{Conclusion: Corporate codes, contract law and regulation}

This contribution has investigated the relation between corporate codes of conduct related to corporate social responsibility issues from the perspective of contracting and contract law. To that end, corporate codes have been described as instruments employed by corporations to regulate their global corporate operations and supply chains, but also to effectively regulate parties outside these corporate and contractual relations. In this respect, this specific form of private regulation rests on a selective and strategic use of contracts and contract law enforcement. From the perspective of contract law as evidenced through the academic debate on the topic and some court decisions, it has been shown that the difficulty in grasping this novel form of private regulation lies in doctrinal constraints related to the reciprocity of contracts, the threshold for contract interpretation, the accommodation of a logic of regulation within the contractual architecture, and the privity of contractual obligations. I have also proposed a normative argument identifying in contract law a legal area that can accommodate this new form of regulation through corporate codes.

This leads to two core conclusions on the relation of contract and regulation. First, in the private sphere one can indeed identify corporate codes as instruments of regulation that partly use the form of contracts and thus are evidence of the fact that the relation between contracts and regulation is blurring. Second, my contribution has sought to highlight the fact that this blurring of a clear divide between contracts and regulation in social practice requires contract law to be responsive to not only the contractual but also the regulatory aspect of the practice. Contract law has itself to reveal and more actively embrace its regulatory capacity.

143 See, for this notion of corporate code enforcement as a complementary measure (with a focus on contractually incorporated codes of conduct), Peterkova Mitkidis, 'Using Private Contracts', p. 53, 77.

${ }^{144}$ I borrow here the term used by Kingsbury in his concept of global administrative law. His understanding of 'publicness' is law that has been 'wrought by the whole society, by the public' and that law 'has to address matters of concern to the society as such', see, e.g., Kingsbury, 'Weighing global regulatory rules and decisions in national courts', p.114. 

